PONTIFÍCIA UNIVERSIDADE CATÓLICA DO RIO DE JANEIRO

A percepção do consumidor em relação às marcas
patrocinadoras do Rock in Rio 2013

Bárbara Fraguito Moreira Gomes

Trabalho de Conclusão de Curso

Centro de CIÊNCIAS SOCIAIS - CCS

DEPARTAMENTO DE AdMINISTRAÇÃO

Graduação em Administração de Empresas 
.

\title{
A percepção do consumidor em relação às marcas patrocinadoras do Rock in Rio 2013
}

\author{
Trabalho de Conclusão de Curso
}

Trabalho de Conclusão de Curso, apresentado ao programa de graduação em Administração da PUC-Rio como requisito parcial para a obtenção do título de graduação em Administração.

Orientadora: Cecilia Mattoso 


\section{Agradecimentos}

Aos meus familiares,

por sempre acreditarem no meu potencial, me ajudarem nos momentos mais difíceis, me dando força, conselhos e me ajudando a superar todas as barreiras.

À professora Alessandra Baiocchi,

que dedicou seu tempo e compartilhou aprendizados comigo desde o período passado, e me evoluiu como aluna.

À minha orientadora Cecília Mattoso,

por acreditar na minha capacidade e me incentivar a desenvolver o meu melhor trabalho. Pela parceria e dicas, que foram fundamentais nessa etapa da vida. 


\section{Resumo}

GOMES, Bárbara. A percepção do consumidor em relação às marcas patrocinadoras do Rock in Rio 2013. Rio de Janeiro, 2015. Número de páginas: 54. Trabalho de Conclusão de Curso - Departamento de Administração. Pontifícia Universidade Católica do Rio de Janeiro.

Este estudo consiste em investigar e analisar como a marca Rock in Rio, agregou valor às marcas patrocinadoras do evento no ano de 2013 através do ponto de vista dos consumidores. Por meio da pesquisa descritiva, o estudo visa conhecer melhor o ponto de vista do público que frequentou o Rock in Rio 2013, em como a marca é percebida por eles, os benefícios em relação às marcas que patrocinaram o evento em termos de conhecimento, associações, qualidade e lealdade à marca e dessa forma investigar se aumentou o envolvimento dos mesmos com as marcas patrocinadoras e se houve alguma alteração na imagem dessas marcas por parte do público que compareceu ao Rock in Rio 2013. Por fim, a pesquisa apontou que os consumidores percebem a marca Rock in Rio como uma marca jovem, associada a características positivas e eles não tiveram dificuldade em lembrar das marcas patrocinadoras, o que conclui que o recall de marca foi bom e a maior parte dos respondentes concorda que o Rock in Rio é um evento ideal para exposição das marcas. Quando ao aumento à lealdade à marca patrocinadora, isto não foi possível verificar.

Palavras- chave

Marcas; Entretenimento; Patrocínio 


\section{Abstract}

GOMES, Barbara. The consumer perceptions toward the sponsoring brands of Rock in Rio 2013. Rio de Janeiro, 2015. Número de páginas p:54 Trabalho de Conclusão de Curso - Departamento de Administração. Pontifícia Universidade Católica do Rio de Janeiro.

This study intends to investigate and analyze how the brand Rock in Rio, added value to the sponsoring brands of the event that occurred in 2013 through the consumer's point of view. Through descriptive surveys, the study aims to better understand the public's point of view who attended the Rock in Rio 2013, in how the brand is perceived by them, the benefits in relation to the brands that sponsored the event in terms of knowledge, associations, quality and brand loyalty and thus investigate whether increased it's involvement of the same with the sponsoring brands and if there was any change in their image by the perceptions of the public who attended the Rock in Rio 2013. Finally, the survey indicated that consumers realize the brand Rock in Rio as a young brand, associated with positive characteristics and they had no trouble remembering the sponsoring brands, which concludes that the brand recall was good and most of the respondents agree that the Rock in Rio is an ideal event to display brands, but only one of them, became more loyal to any brand that sponsored the event.

Key-words

Brands; Entertainment; Sponsorship 


\section{Sumário}

1 O tema e o problema de estudo 1

1.1. Introdução ao tema e ao problema do estudo 1

1.2. Objetivo do estudo 4

1.3. Objetivos intermediários do estudo 4

1.4. Delimitação e foco do estudo 4

1.5. Justificativa e relevância do estudo 4

2 Revisão de literatura 6

2.1. Marca 6

2.1.1. Envolvimento com a marca $\quad 7$

2.2. O Valor da Marca (Brand Equity) 8

2.2.1. Proporcionando Valor Para os Clientes 11

2.2.2. Proporcionando Valor Para a Empresa 12

2.3. Patrocínio de eventos 14

2.4. Marketing de Experiência 15

3 O Rock in Rio 18

3.1. A História do Rock in Rio 18

3.2. Rock in Rio 2013

4 Métodos e procedimento de coleta e análise de dados do estudo 21

4.1. Etapas de coleta de dados 21

4.2. Universo e amostra 21

4.3. Coleta de dados utilizados no estudo 22

4.4. Tratamento e análise dos dados coletados para o estudo 23

4.5. Limitações do Estudo 23

5 Apresentação e Análise dos Resultados 25 
5.1. Perfil dos respondentes 26

5.2. Comportamento do consumidor em relação ao Rock in Rio 201328

5.2.1. Número de dias frequentados pelos respondentes 28

5.2.2. Atributos que mais incomodou o público no Rock in Rio 201328

5.2.3. Motivos por ter frequentado o Rock in Rio 2013

5.3. Associação à marca Rock in Rio 30

5.3.1. Associação espontânea 30

5.3.2. Associação a partir de uma lista dada 31

5.4. Marcas patrocinadoras 31

5.4.1. Lembrança de marca (Top of Mind) 31

5.4.2. O festival Rock in Rio como evento para exposição das marcas 33

5.5. Experiência de marca oferecido pelas marcas patrocinadoras $\quad 34$

5.6. Recompra do evento Rock in Rio 36

6 Conclusões e recomendações para novos estudos 37

6.1. Sugestões e recomendações para novos estudos 38

7 Referências Bibliográficas $\quad 40$

$\begin{array}{ll}\text { Anexo } 1 & 43\end{array}$

\section{Lista de Figuras}

Figura 1 - Rock in Rio 2013 - Business in Numbers (2013) .............................. 3

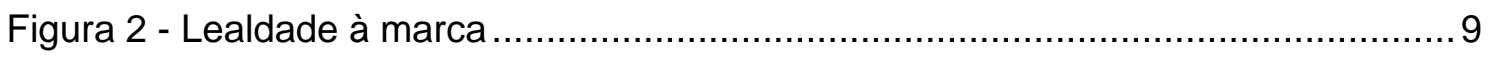

Figura 3 - Brand Equity ......................................................................... 13

Figura 4 - Experimental Providers (exPros) - "Provedores de Chave Experimental" ...17

Figura 5 - Perfil da amostra quando à idade ........................................................ 26

Figura 6 - Perfil da amostra do estilo musical que os respondentes mais gostam.......27

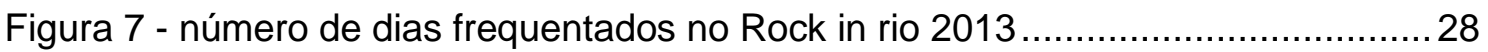


Figura 8 - Motivos por ter frequentado o Rock in Rio 2013 ..................................... 30

Figura 9 - Associação espontânea à marca Rock in Rio ........................................... 30

Figura 10 - Associação à marca rock in rio, a partir de uma lista dada ....................... 31

Figura 11 - Primeira marca patrocinadora a ser lembrada (Top of Mind) ..................... 32

Figura 12 - Lembrança das marcas patrocinadoras .................................................. 33

Figura 13 - Roda Gigante oferecida pela marca Itaú ............................................... 35

Figura 14 - Tirolesa oferecida pela marca Heineken ............................................ 35

Figura 15 - Montanha Russa oferecida pela marca Chilli Beans ............................... 35

Figura 16 - Turbo Drop oferecido pela marca Trident............................................. 36

\section{Lista de Gráficos}

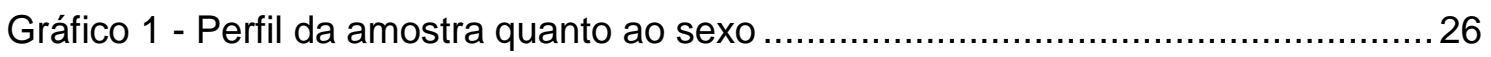

Gráfico 2 - Recompra do evento Rock in Rio .............................................................. 36

\section{Lista de Tabelas}




\section{0 tema e o problema de estudo}

Esse capítulo volta-se à apresentação do tema que se pretende desenvolver e do problema de estudo.

Assim, apresenta-se o problema que suscitou a proposta de investigação e respectivos objetivos de pesquisa. Na sequência, são indicadas as suposições e as hipóteses do estudo e se informa a relevância e justificativa do estudo e a delimitação e foco do estudo.

\subsection{Introdução ao tema e ao problema do estudo}

Em 1985 o Brasil se libertava de mais de 21 anos de ditadura. O clima das Diretas Já ${ }^{1}$ nutria um sonho de uma população que há mais de vinte anos não podiam escolher seu presidente da república. Esse era o momento em que a juventude queria ir para as ruas celebrar a conquista pela democracia e liberdade (CHULAM, 2004; CARNEIRO, 2011).

Foi neste momento da nossa história que o empresário carioca Roberto Medina, pensou em promover um show jamais visto antes pela população brasileira, um megaconcerto que pararia o Brasil: o Rock in Rio. Porém, a ideia não era tão simples, o Brasil nunca havia realizado nada parecido, como parâmetro, tinham dois festivais internacionais, o Woodstock, em Nova lorque e o festival na llha de Wight, na Inglaterra (CHULAM, 2004).

Ao mesmo tempo, a cervejaria Brahma sentia necessidade de rejuvenescer sua marca, desenvolvendo a ideia de lançar uma cerveja jovem para captar um novo público-alvo e o Rock in Rio seria o evento ideal para reunir esse público com a marca. Assim, o publicitário conseguiu o seu primeiro patrocinador para o evento, a Brahma (CHULAM, 2004).

Era necessário desenvolver uma estratégia integrada de marketing, comunicação, transmissão na televisão, patrocinadores, entre diversos outros fatores, isso por que o Rock in Rio não conseguiria se sustentar apenas da bilheteria. Pelos

${ }^{1}$ Diretas já foi um movimento do ano de 1983, que propunha eleições presidenciais diretas. Aconteceu no governo de governo de João Batista Figueiredo e teve apoio dos partidos PMDB e PDS. Disponível em:

< http://www.infoescola.com/historia/diretas-ja/> Acesso em fevereiro/2015. 
cálculos do empresário, a verba vinda dos ingressos não representaria mais que $30 \%$ dos custos do evento. Para Roberto Medina, "o Rock in Rio não era pra ser megalômano, mas nasceu megalomaníaco por que se não tivesse público suficiente ele não se pagava" (CARNEIRO, 2011, p.23).

Medina cruzou fronteiras em busca de bandas estrangeiras e grandes nomes da música internacional, como George Benson e Iron Maiden, além de ir atrás de empresários e jornalistas para convencê-los de que sua ideia era viável.

O festival foi um sucesso. Através do Rock in Rio, o mercado de show business passou a ser uma realidade para empresários brasileiros conquistando a credibilidade do público e das empresas patrocinadoras para promover a sua marca (CARNEIRO, 2011).

\footnotetext{
"O Rock in Rio é um projeto de comunicação de um ano que termina com o maior festival de música. A marca Rock in Rio é um colchão para que todas as outras marcas possam falar e aproveitar 0 conteúdo. Criamos uma plataforma para permitir que os patrocinadores falem da gente" (MEDINA, 2011) Disponível em <http://promoview.com.br/acaopromo/146137-rock-in-rio-um-show-deativacao/>. Acesso em: novembro/2014
}

De acordo com Melo Neto (1999, apud BEZERRA, 2001) para o público que costuma frequentar esses grandes eventos, associar a experiência ao patrocinador é inevitável, tornando a marca mais familiar e forte. Dessa forma, os eventos contribuem não só para a fidelização dos antigos clientes, mas para a expansão e a conquista de novos mercados.

Segundo Kotler e Keller (2006), ao patrocinar um evento, a empresa pode construir sua imagem de marca perante seus consumidores atraindo sua atenção, embora o efeito sobre os frequentadores a respeito do conhecimento e preferência da marca varie dependendo da qualidade do produto, do evento em si e de como ele é realizado.

$\mathrm{Na}$ edição de 2013 os ingressos se esgotaram em pouco mais de quatro horas, mais de 595 mil pessoas se juntaram ao festival e segundo dados divulgados pelo IBOPE (2013) o evento atraiu cerca de 85.000 fãs por dia. O festival contou com sete principais patrocinadores: Clube Social, Coca-Cola Zero, Heineken, Itaú, Oi, Trident e Volkswagen (GOMES, 2013).

A Volkswagen teve o maior envolvimento com o público presente através do marketing de experiência com 1,4\%, em contrapartida, o Banco Itaú teve maior audiência com mais de 6 milhões de espectadores. Foram mais de 1.100 posts nas 
redes sociais dos sete patrocinadores, principalmente com vídeos no site do Youtube por pessoas que estavam dentro do festival, como demonstra na figura abaixo:

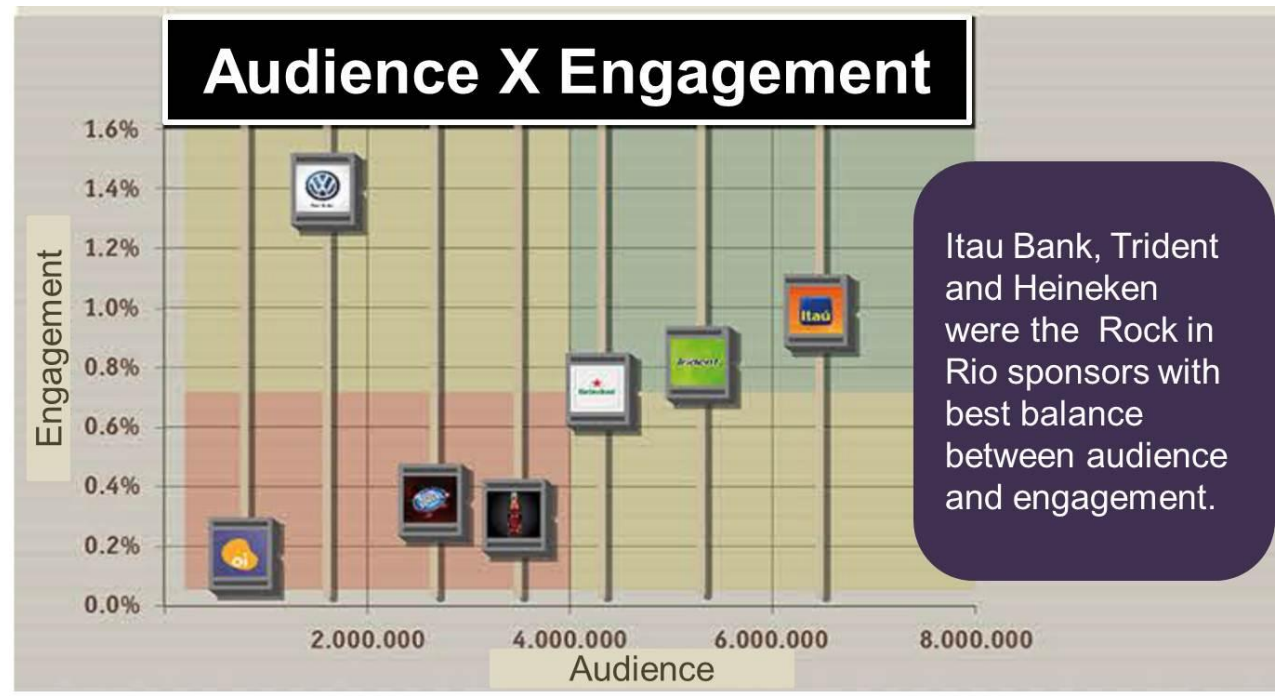

Figura 1 - Rock in Rio 2013 - Business in Numbers (2013)

Disponível em <http://www.bricexpansion.com/rock-in-rio-business-numbers/>.

As interações entre consumidores e as sete principais marcas patrocinadoras do Rock in Rio cresceu 11\%, enquanto que as 25 principais marcas brasileiras tiveram um crescimento de apenas $2 \%$, no mesmo período.

Dado este panorama, o presente trabalho se propõe a investigar a seguinte questão: Como a marca Rock in Rio, agregou valor às marcas patrocinadoras do evento no ano de 2013 através do ponto de vista dos consumidores? 


\subsection{Objetivo do estudo}

O objetivo principal desse estudo consiste em investigar e analisar como a marca Rock in Rio agregou valor às marcas patrocinadoras do evento no ano de 2013 através do ponto de vista dos consumidores.

\subsection{Objetivos intermediários do estudo}

Para se alcançar o objetivo final do estudo, aproximando-se assim da resolução do problema de pesquisa, deve-se passar por algumas etapas, aqui denominadas objetivos intermediários. São eles:

$\checkmark$ Como os consumidores percebem a marca Rock in Rio.

$\checkmark$ Levantar como os consumidores percebem os benefícios em relação às marcas que patrocinaram o Rock in Rio 2013 em termos de conhecimento, associações, qualidade e lealdade.

$\checkmark$ Estimar o nível de conhecimento do público que frequentou o evento em relação às marcas patrocinadoras do Rock in Rio 2013.

$\checkmark$ Investigar se aumentou o envolvimento dos consumidores com as marcas patrocinadoras e se houve alguma alteração na imagem dessas marcas por parte do público que compareceu ao Rock in Rio 2013.

\subsection{Delimitação e foco do estudo}

O presente estudo delimita-se à percepção em relação às marcas do público na faixa etária entre 18 e 35 anos, que frequentou o Rock in Rio no ano de 2013, que ocorreu no mês de setembro na cidade do Rio de Janeiro.

\subsection{Justificativa e relevância do estudo}

As informações que esse estudo pretende produzir podem se mostrar de interesse para outras pesquisas e trabalhos do meio acadêmico, visto que possam vir a permitir uma reflexão sobre o crescimento do patrocínio de eventos de música por parte das 
empresas privadas e assim auxiliar o interessado em usar esse trabalho como referencial para uma nova pesquisa.

Os resultados a serem alcançados por esse estudo podem se mostrar de interesse para as empresas patrocinadoras ou que ainda não usam o patrocínio como estratégia de comunicação, por ajudá-las a compreender melhor a importância em destinar uma parte da sua verba em patrocínios de eventos musicais, não apenas o Rock in Rio, e assim, estabelecer uma estratégia competitiva, visto que é um mercado em crescimento e que seus concorrentes estão investindo cada vez mais em patrocínio de eventos musicais.

Os resultados também poderão ser úteis para agências/fornecedores persuadirem seus clientes com propostas e evidências de que o patrocínio de eventos e mais especificamente do Rock in Rio é uma estratégia de marketing em ascensão que deve ser explorada pelas empresas.

Dessa forma, o estudo procura entender melhor o mercado de patrocínio do Rock in Rio 2013 e em como pode ser útil para futuras pesquisas e análises sobre o mercado, além de construir um acervo específico para empresas interessadas e profissionais de comunicação que possam se utilizar desse estudo como base para realização de ações em futuros festivais do Rock in Rio. 


\section{Revisão de literatura}

Neste capítulo são apresentados e discutidos aspectos conceituais e estudos relacionados ao tema de estudo em investigação e que servirão de base para a análise realizada.

Esta seção está dividida em quatro partes e aborda, respectivamente, a conceitualização da marca e o envolvimento com a mesma, a questão de como o brand equity agrega valor para a empresa e para os clientes, o patrocínio de eventos como uma forma de comunicação adotada pelas empresas para agregar valor à marca, e por fim o marketing de experiência como uma estratégia para atrair e fidelizar clientes, conceituando e mostrando as perspectivas de diversos autores.

\subsection{Marca}

Acredita-se que o mercado está situado no que denominamos "a era das marcas", tendo em vista que elas estão presentes em nosso cotidiano há mais de um século, porém só começaram a ser discutidas com seriedade a partir do século $X X$, sendo importante destacar o papel das marcas no cenário atual (TAVARES, 2003).

Para Roberts (2005), as marcas sofreram grandes mudanças desde o seu início. No princípio, quando os produtos não a possuíam, eles eram praticamente instintas. Ao longo dos anos, as marcas ficaram mais próximas à necessidade das empresas em design, qualidade, preço, utilidade, disponibilidade, inovação e segurança.

Pinho (1996), afirma que o conceito da marca é definido por um nome, termo, sinal, símbolo, desenho, ou combinação dos mesmos, que pretende identificar os bens e serviços de um vendedor ou grupo de vendedores e diferenciá-los daqueles dos concorrentes.

Aaker (1998) complementa que a marca pode ser um nome diferenciado e/ou símbolo, tal como uma marca registrada, desenho, embalagem, ou um logotipo.

De acordo com Kotler e Keller (2012), o papel da marca é de identificar a origem ou o fabricante de um produto, permitindo que os seus consumidores possam atribuir à responsabilidade pelo seu desempenho adquirido a um determinado fabricante ou consumidor. Aaker (1998) completa que uma determinada marca sinaliza ao 
consumidor a origem do produto e protege tanto o consumidor quanto o fabricante dos concorrentes que oferecem produtos que muitas vezes podem parecer idênticos.

Pinho (1996) diz ainda que a marca passa a significar, além do produto em questão, os valores e atributos tangíveis e intangíveis que os diferencia dos produtos similares. Ainda segundo o autor, o avanço da tecnologia tem permitido o oferecimento de produtos com especificações técnicas iguais, ou seja, com as mesmas características. Dessa forma, os canais de distribuição, tornaram-se os mesmos e os investimentos em comunicação mercadológica ficaram bastante próximos, o que resultou em pressões iguais na demanda. Ainda segundo o autor, todos esses fatores levaram a uma valorização do registro dos produtos e serviços, ou seja, da criação da marca como um elemento exclusivo de diferenciação.

\subsubsection{Envolvimento com a marca}

Segundo Pinho (1996), a comunicação regular com os clientes é de grande importância para mantê-los atualizados quanto às novas informações sobre produtos e serviços. Porém, para realizar uma verdadeira interação entre a marca e o cliente é necessário que além da comunicação convencional, aconteça também o envolvimento do consumidor, que deve ter espaço para fazer críticas com relação aos produtos e serviços, assistir a uma apresentação patrocinada pela marca, ou comparecer a inauguração com a intenção de estabelecer um relacionamento pessoal.

Para Kotler e Keller (2006), pela experiência e aprendizagem, as pessoas adquirem crenças e atitudes, que por sua vez influenciam no comportamento de compra. Uma crença é um pensamento descritivo que alguém mantém a respeito de alguma coisa. As crenças sobre os atributos e benefícios de um produto ou marca influenciam nas decisões de compra. Tão importante quanto elas é a atitude. Uma atitude corresponde a avaliações, sentimentos e tendências de ação duradouros, favoráveis ou não, a algum objeto ou ideia.

Solomon (2002, p.101) acredita que os consumidores podem formar relacionamentos fortes com produtos ou serviços e define o envolvimento da seguinte maneira:

"O envolvimento é definido como a relevância do objeto percebida por uma pessoa com base em suas necessidades, valores e interesse inerentes. A palavra objeto é usada no sentido genérico se refere a um produto (ou uma marca), um anúncio ou situação de compra." 
Dependendo de como a marca é estabelecida, os consumidores podem avaliar um produto idêntico de forma diferente. Eles conhecem as marcas por meio de experiências anteriores com o produto e com o plano de marketing atingido por ele, identificando quais satisfazem suas necessidades e quais deixam a desejar (KOTLER e KELLER, 2012).

Além disso, os autores também afirmam que os consumidores que são fieis às marcas proporcionam às organizações previsibilidade e segurança além de criar barreiras que tornam a concorrência mais difícil. Essa fidelidade também significa que os consumidores têm disposição de pagar um preço mais elevado para adquirir determinado produto ou serviço. Ainda que algum concorrente tente conquistar um cliente fiel a uma determinada marca, ele terá dificuldade em igualar-se às impressões duradouras formadas na mente das pessoas e organizações, graças a alguns anos de atividade de marketing e experiência com o produto.

\subsection{O Valor da Marca (Brand Equity)}

O conceito de brand equity se estabeleceu no mercado, em meados da década de 1980, período em que ocorreram grandes processos de compras e fusões de empresas multinacionais, impactando assim as marcas já solidificadas no mercado. (PINHO, 1996).

De acordo com Strunk, (2001, p. 32), o brand equity é o resultado de todas as qualidades e atributos que estão relacionados a uma marca, sendo o poder de convencimento de uma marca em relação ao seu consumidor no momento da compra. É o que faz o consumidor escolher uma determinada marca dentre todas as outras concorrentes, ou seja, é tudo de tangível e intangível que a marca possui e que contribui para seu crescimento lucrativo.

Kotler e Keller (2006, p.210) complementam o conceito de brand equity como sendo o valor agregado atribuído a produtos e serviços. Esse valor pode se refletir no modo como os consumidores pensam, sentem e agem em relação a uma determinada marca. Com base nos autores referenciados, pode-se entender que brand equity é tudo que lida com o valor da marca, mas que vai além do patrimônio físico, sendo o valor da imagem e da lealdade dos seus clientes.

Para ter valor, Pinho (1996) afirma que a marca precisa ter coerência e ser valorizada. O valor da marca é o resultado do grau de lembrança mais o grau de fidelidade que os consumidores têm sobre ela e a sua força de imagem. Sendo assim, as marcas desempenham primordialmente a função de identificar os produtos e 
serviços por eles assinalados e diferenciá-los daqueles produzidos pela concorrência (PINHO, 1996, p.11).

Aaker (1998, p.16) introduz o conceito de brand equity como sendo um conjunto de ativos e passivos ligados a uma determinada marca, seu nome e seu símbolo, e proporcionam o valor para um produto ou serviço, não apenas para o consumidor, mas também para a empresa.

Sendo assim, Cobra (2014) complementa Aaker, dizendo que um dos principais efeitos do aumento de valor de uma determinada marca está ligada à lealdade dos consumidores em relação às mesmas. Com isso, Aaker afirma que a lealdade é o centro do brand equitiy e reflete a probabilidade de um consumidor substituir ou não uma marca pela outra. Porém, à medida que a lealdade à marca aumenta, a vulnerabilidade dos consumidores à concorrência diminui.

Aaker (1998) vai além e afirma que o conceito de brand equity, está baseado em cinco dimensões: lealdade à marca, conhecimento da marca, qualidade percebida, associações da marca e outros ativos da empresa.

A lealdade é a essência do brand equity e é qualitativamente diferente das outras dimensões principais, por estar mais ligada à experiência de uso. A lealdade não pode existir sem a compra prévia e experiência de uso (AAKER, 1998).

A figura abaixo ilustra os cinco níveis de lealdade à marca, que segundo o autor é um dos pilares de marketing.

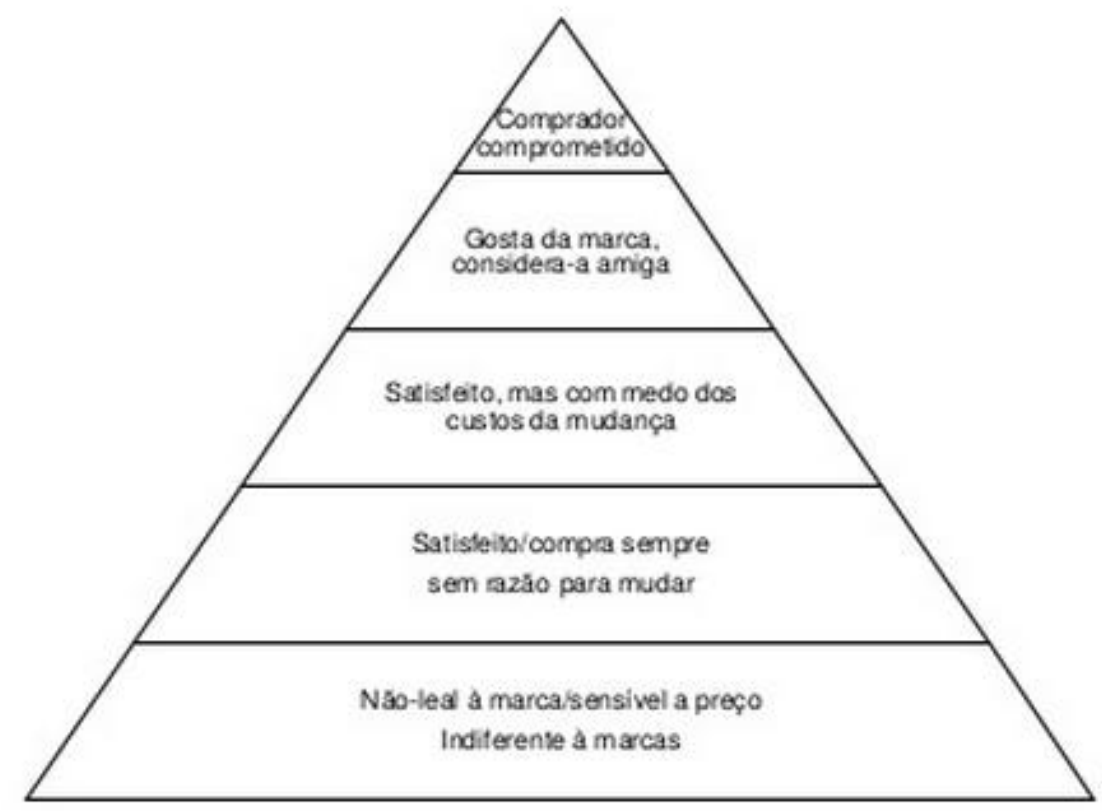

Figura 2 - Lealdade à marca

Fonte: Aaker, 1998 p. 41. 
Cada um desses níveis representa um desafio diferente ao marketing e um diferente nível de ativo para ser explorado e gerenciado.

No nível mais baixo, encontram-se aqueles consumidores que são completamente indiferentes à marca. Para esse consumidor, o nome da marca tem pouca importância na decisão de compra dele, ou seja, qualquer marca que estiver à venda ou que lhe seja conveniente no momento será preferida.

O nível acima inclui compradores que estão satisfeitos com o produto, ou pelo menos não insatisfeitos. São compradores que podem ser denominados habituais, o que requer um esforço maior por parte dos concorrentes, pois é necessário criar um benefício visível com a mudança, embora possa ser difícil convencê-los a mudar já que não estão em busca de alternativas.

No terceiro nível estão aqueles compradores leais, mas suscetíveis a mudanças, que também estão satisfeitos mas temem alguns esforços necessários como o custo, tempo, dinheiro, e performance associados. Para atrair esses compradores, os concorrentes têm de superar os custos da mudança mediante a oferta de um atrativo ou de um benefício compensatório.

O quarto nível, são os compradores que realmente gostam da marca. Essa preferência pode ser dada por uma associação, seja um símbolo ou um conjunto de experiências de uso ou com uma alta qualidade percebida. Esse nível de compradores possui uma ligação emocional de amizade com a marca.

Por fim, o nível mais elevado da pirâmide representa os consumidores comprometidos com a marca. Eles têm orgulho de serem descobridores e usuários da mesma. O valor do consumidor comprometido não é tanto pela contribuição individual, mas pela capacidade de atração e divulgação das marcas da marca aos outros níveis.

Pinho (1996) complementa que a manutenção da lealdade dos clientes com base em relações desenvolvidas individualmente influencia positivamente a imagem de marca, já que um dos elementos preponderantes na sua formação são as relações estabelecidas entre consumidores e marcas ao longo do tempo.

A segunda dimensão do brand equity diz respeito ao conhecimento da marca. As pessoas gostam daquilo que é reconhecível. A recordação é uma condição necessária para ser levada em conta, e também pode influenciar sutilmente as decisões de compra (Aaker, 1998). O autor também afirma que as pessoas tendem a realizar compras de produtos e serviços quando a marca lhe parece familiar, pois passa mais confiança. Sendo assim, o conhecimento de marca é importante para que ela seja considerada como uma alternativa de compra.

Ainda segundo Aaker, a terceira dimensão é um fator importante na preferência dos consumidores, que é a percepção que eles têm em relação à qualidade de uma 
determinada marca. Essa percepção não está relacionada diretamente às especificações técnicas do produto, mas sim à percepção que o consumidor tem do produto como um todo, da venda de produtos e serviços e da aquisição dele.

A associação à marca é a quarta dimensão do brand equity. Através dela se pode mudar a forma conforme a informação é processada e recordada pelas pessoas proporcionando diferenciação e razão-de-compra. Aaker diz que a imagem que a marca produz pode proporcionar uma razão de compra para atrair os consumidores. $A$ associação que pode estar relacionada à marca é de algum sentimento ou atitude. Assim, o autor afirma que a marca com associações positivas ficará muito bem colocada com um atributo desejável, como serviço amigável, ou ocupará uma posição distinta daquelas dos concorrentes (Aaker, 1998 p. 115).

Por fim, a última dimensão do brand equity, outros ativos da empresa, são constituídos por patentes, marcas registradas e relações com os canais de distribuição. Esses ativos podem ter diferentes formas e devem estar ligados às marcas quando forem de interesse (PINHO, 1996).

Nesse âmbito, Aaker (1998) afirma que o desenvolvimento de uma marca com o enfoque no seu aumento de valor é importante, pois o seu valor poderá ser calculado tanto pelas empresas como também pelos seus consumidores.

\subsubsection{Proporcionando Valor Para os Clientes}

Tavares (1998) argumenta que o valor da marca baseado no consumidor é positivo, quando o consumidor está familiarizado com ela e alimenta, na memória, alguma associação favorável e única dessa marca; a resposta favorável, por usa vez, aumenta a receita, reduz os custos e aumenta os lucros.

Aaker (1998) complementa que os ativos do brand equity geralmente acrescentam ou subtraem valor para os consumidores e ajudam a interpretar, processar e acumular grande quantidade de informações sobre produtos e marcas. Podem também afetar a confiança do consumidor na decisão de compra que considera o impacto do nome da marca. O mais importante é o fato de que tanto a qualidade percebida, como as associações da marca, pode aumentar a satisfação do consumidor com a experiência de utilização.

Segundo Kotler e Keller (2012, p. 260), existem três elementos fundamentais para a construção do brand equity baseado no cliente. No primeiro, surgem diferenças na resposta do consumidor, se não há diferenças, o nome da marca do produto pode 
ser classificado basicamente como uma commodity ${ }^{2}$. Em segundo lugar, diferenças nas respostas são resultado do conhecimento que o consumidor tem da marca e todos os pensamentos, sensações, imagens, experiências e crenças associadas a ela. E por último, o brand equity se reflete nas percepções, preferências e comportamentos relacionados com todos os aspectos do marketing de uma determinada marca.

\subsubsection{Proporcionando Valor Para a Empresa}

Para as empresas, as marcas representam uma prioridade valiosa que pode influenciar no comportamento do consumidor, ser comprada e vendida, e ainda, oferecer a segurança de receitas futuras e estáveis para o seu proprietário. Muitas vezes altas quantias são pagas e negociadas por marcas em fusões e aquisições e outras vezes justificadas pela premissa da expectativa de lucros extras, assim como pela dificuldade e despesa envolvida na criação de marcas semelhantes a partir do zero (KOTLER e KELLER 2012 p.259).

Sendo assim, de acordo com Aaker (1992), o brand equity tem papel fundamental em adicionar valor para a empresa através do aumento de seis ativos, como podem ser vistos na figura 3 :

${ }^{2}$ Commodity é uma palavra em inglês que significa mercadoria. Esta palavra é usada para descrever produtos de baixo valor agregado. Disponível em:

< http://www.significados.com.br/commodities> Acesso em 27 de abril de 2015. 


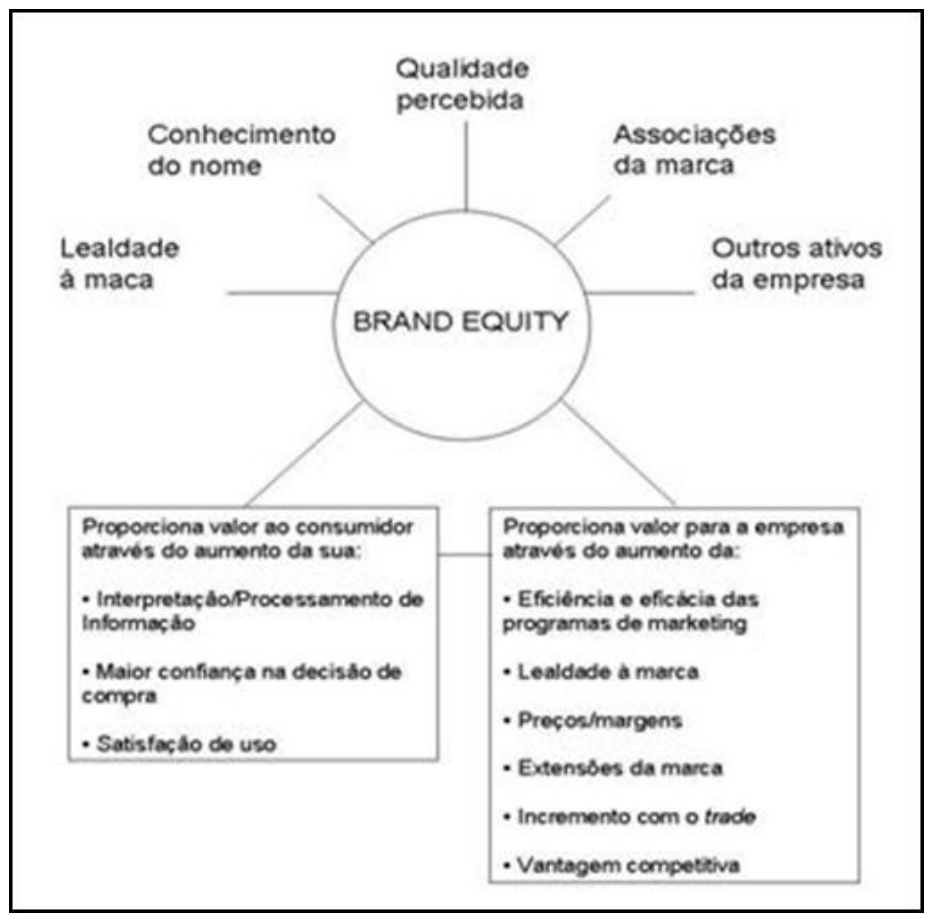

\section{Figura 3 - Brand Equity}

Fonte: Aaker, 1998, p.18

De acordo com Aaker (1992), o brand equity pode aumentar a eficiência e eficácia dos programas de marketing. Uma propaganda que anuncia um novo recurso ou modelo é mais provável de ser lembrada e estimular a ação se o potencial consumidor tem uma percepção boa em relação à marca.

Manter os clientes existentes é muito menos custoso do que atrair novos, em adição, clientes fiéis, em alguns casos, também podem atrair outras pessoas usando o produto ou aconselhando terceiros a usá-lo. Seguindo essa linha, Aaker (1992) ressalta a importância da lealdade à marca. É preciso reforçá-la principalmente na hora da compra para reduzir o risco da concorrência, que tenta inovar para assim obter vantagens em relação à outras marcas. É difícil também para os concorrentes se comunicarem com os usuários satisfeitos das marcas porque têm pouca motivação para aprender sobre as alternativas.

O brand equity normalmente vai fornecer margens mais elevadas para os produtos permitindo preços mais elevados de forma a reduzir a dependência das promoções. Em muitos contextos, os elementos de brand equity servem para apoiar preços mais premium. Ainda segundo o autor, o brand equity pode proporcionar uma plataforma para o crescimento por extensões de marca. (AAKER, 1992). 
O valor da marca pode alavancar o canal de distribuição. Assim como os clientes, os membros do canal têm menos incerteza lidando com um nome de marca que já alcançou reconhecimento e estabeleceu associações fortes. Além disso, marcas com o nome mais consolidado no mercado podem desempenhar um papel na liderança da comercialização entre linhas e produtos podendo ganhar força através da utilização de impacto visual do produto nas prateleiras das lojas e em promoções (AAKER, 1992).

Finalmente, os ativos patrimoniais da marca fornecem à empresa uma vantagem significativa: a barreira que impede os clientes de mudarem para um concorrente.

\subsection{Patrocínio de eventos}

A empresa pode associar-se a um evento por meio de patrocínios. Este pode ser definido mediante pagamento em dinheiro, prestação de serviços ou fornecimento de produtos a um evento, explorando comercialmente o que esta atividade oferece (COSTA, 2004). A promoção da marca, segundo Melo Neto (2000), é o mais importante do patrocínio; em seguida o aumento de vendas, popularizar a marca na mídia e conseguir atingir novos clientes e mercados.

Segundo Pope e Voges (1999), o patrocínio é o oferecimento de recursos por uma organização ou pessoa física (denominado patrocinador), sejam eles de equipamentos ou dinheiro, para outra organização ou pessoa física. Em retorno, tem direito aos benefícios corporativos e estratégicos de promoção, marketing e mídia.

Patrocinar eventos é propor um tipo de comunicação distinta com os consumidores, pois quem patrocina automaticamente tem seu nome ligado à parte do evento e compartilha de um momento que pode ser especial na vida dos consumidores. Dessa forma, ao patrocinar um evento, as empresas devem fazer com que o público retenha na memória e identifique as marcas que são patrocinadoras. $O$ fundamental ao patrocinar um evento é criar valor e manter o conhecimento da marca. Para atingir esse conhecimento, identificação e lembrança, são necessárias duas tarefas: ganhar a identidade do nome da marca e conectá-la com a classe do produto (AAKER, 1998).

O patrocínio vem sendo usado frequentemente pelo marketing tanto de empresas do setor público quanto privado. O resultado do crescimento mundial do patrocínio pode ser notado nos meios de marketing e de negócios, com fortes 
investimentos, e diversos consumidores e stakeholders se beneficiando desse crescimento (BOWDIN et al, 2006).

\begin{abstract}
"Do ponto de vista das empresas, há uma série de motivos para patrocinar eventos, são eles: criar identificação com um mercado-alvo ou com um estilo de vida específico; aumentar a conscientização do nome da empresa ou do produto; criar ou reforçar percepções do consumidor quanto a associações-chave com a imagem da marca; aperfeiçoar as dimensões da imagem corporativa; criar experiências e provocar sensações; expressar compromisso com a comunidade ou com questões sociais; entreter os principais clientes ou recompensar funcionários chave; e permitir oportunidades de divulgação ou promoções" (KOTLER e KELLER, 2006 p. 591).
\end{abstract}

Para Kotler e Keller (2006), o conhecimento estratégico por parte dos profissionais vem se aperfeiçoando para poderem saber com quem e como se relacionar, em detrimento do dinheiro envolvido ser alto, e as oportunidades de eventos potencialmente patrocináveis serem abundantes.

Nesse contexto, o que deve ser buscado em um patrocínio é associar uma marca (patrocinador) a um evento (patrocinado), resultando em um ganho de credibilidade, associações e as emoções positivas que o evento proporciona ao seu público, por parte do patrocinador.

O sucesso de uma ação de patrocínio passa pela escolha dos eventos apropriados, pela criação do plano de patrocínio ideal para o evento, e pela avaliação dos efeitos que ele produz.

Devido à grande diversidade de oportunidades existentes e do alto investimento envolvido, os profissionais de marketing têm se tornado mais seletivo quando se trata da escolha dos eventos a serem patrocinados. O objetivo de marketing e a estratégia de comunicação que foram definidos para a marca devem ser cumpridos pelo evento. O público-alvo deve ser correspondido, e o evento deve contar com o reconhecimento suficiente, possuir a imagem desejada a ser capaz de criar efeitos desejados e esperados pela marca para o seu mercado-alvo. Os consumidores devem atribuir imagens favoráveis ao patrocinador por seu envolvimento no evento.

\title{
2.4. Marketing de Experiência
}

De acordo com Schmitt (2000), em uma variedade de mercados e indústrias, diversas organizações passaram a usar a técnica do marketing de experiência para desenvolver novos produtos, comunicar-se com os consumidores, melhorar 0 
resultado das vendas, selecionar parceiros de negócios, mapear o ambiente e desenvolver seus websites. Porém, essas transformações não mostram sinais de desaceleração, já que mais e mais, profissionais da área estão fugindo do tradicional marketing dos "anúncios e benefícios" para explorar a criação de experiência e dessa forma, se aproximar mais dos seus consumidores.

Para Kotler e Keller (2012), fazer parte de um momento relevante na vida pessoal dos consumidores por meio de eventos e experiências pode ampliar e aprofundar o relacionamento de uma empresa ou marca com o mercado-alvo. Os autores ainda afirmam que a ideia do marketing de experiências não é vender algo, mas demonstrar como uma marca pode enriquecer a vida de um cliente.

Kotler e Keller (2012) afirmam que o marketing de experiência visa proporcionar oportunidades únicas e inesquecíveis para o consumidor, uma vez que os produtos e serviços estão cada vez mais comuns.

Em uma pesquisa, quatro de cada cinco entrevistados achavam que participar de um evento ao vivo era mais envolvente do que qualquer outra forma de comunicação. A grande maioria também afirmou que $o$ marketing experiencial lhe fornecia mais informações do que as outras formas de comunicação, e que provavelmente faria com que contasse aos outros como e participar de um evento e fosse receptiva a outras ações de marketing da marca. (KOTLER e KELLER, $2006 \mathrm{p}$. 591).

Schmitt (2000) introduz uma nova abordagem do marketing de experiências, nominado por ela como SEMs (Strategic Experimental Modules), que inclui experiências sensoriais (sentido); experiências afetivas (afeto); experiências cognitivas e criativas (pensamento); experiências físicas e estilos de vida (ato); e a identidade social que resultam de experiências relativas a um grupo de referência ou cultura (relacionamento).

Ainda segundo a autora, a partir do SEMs, podem ser usadas sete ferramentas táticas experienciais (comunicações, identidade visual e verbal, senso de produtos, cobranding, ambiente espacial, mídia eletrônica e pessoas) para criação de campanhas com o intuito de atingir os aspectos estratégicos, como o sentido, a emoção, o pensamento, a atitude, ou o relacionamento com o consumidor em geral. Como pode ser visto na figura 4 : 


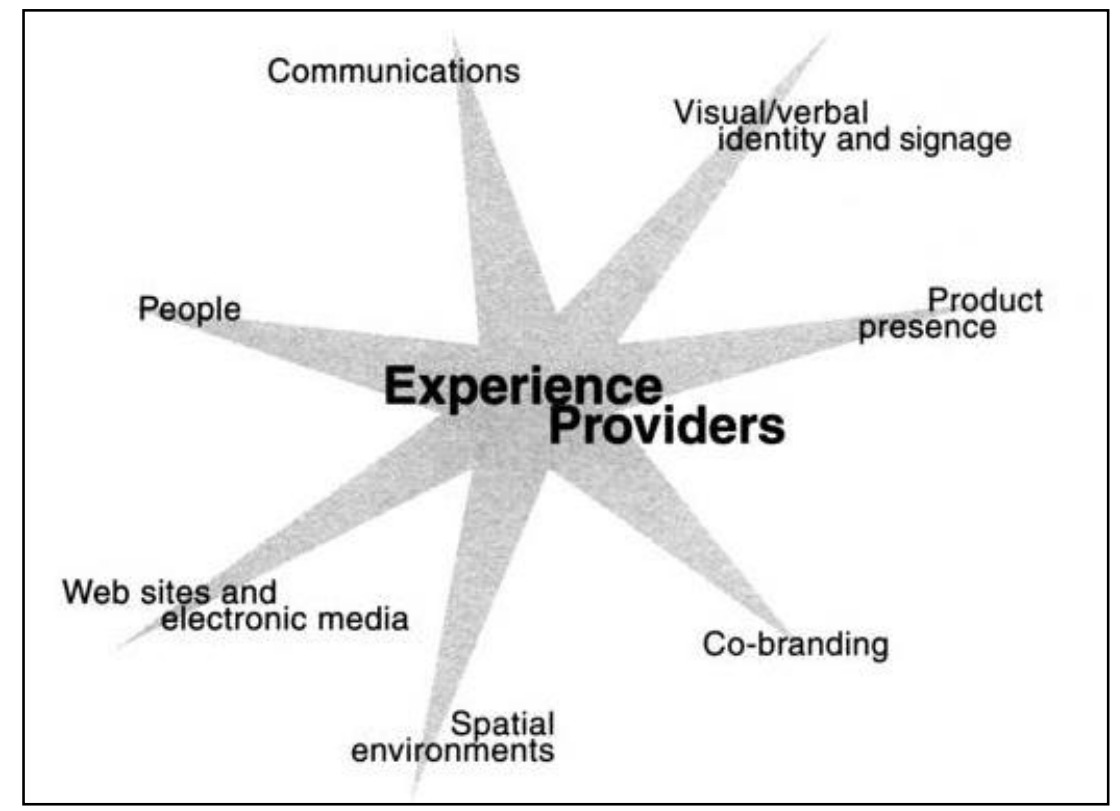

Figura 4 - Experimental Providers (exPros) - "Provedores de Chave Experimental" Fonte: Schimitt, 2000, p. 73. 


\section{O Rock in Rio}

\subsection{A História do Rock in $\mathrm{Rio}^{3}$}

Roberto Medina, um publicitário com realizações em grandes eventos, como o show do Frank Sinatra no Maracanã em 1980, até então o maior show de um artista solo, vislumbrou que o Brasil tinha um grande potencial para sediar grandes shows internacionais, podendo trazer artistas do mundo todo, gerando não apenas emprego como turismo para o país.

Ao mesmo tempo, a cervejaria Brahma tinha uma necessidade de rejuvenescer sua marca, e através de uma estratégia de marketing criada pela agência de publicidade Artplan, também fundada por Roberto Medina decidiu-se criar um produto novo, a Malt 90, já que era muito arriscado mexer na marca que tinha uma grande participação no mercado. Surgiu então a ideia de lançar uma cerveja jovem, para um público jovem com a realização de um evento para esse público-alvo. Foi assim que nasceu o Rock in Rio, maior festival de música de todos os tempos, com a primeira edição em 1985.

“(...) e numa campanha considerada revolucionária à época, a agência sugeriu a realização de um festival de música onde os jovens pudessem se confraternizar e tomar cerveja" (MEDINA). Disponível em <http://www.meioemensagem.com.br/home/marketing/noticias/ 2011/09/22/Megaespetaculo-de-interacao-entre-marcas-econsumidores.html>

A primeira edição do festival aconteceu no Rio de Janeiro, no bairro de Jacarepaguá. Em uma área de 250 mil metros quadrados, batizado pelo próprio empresário como a Cidade do Rock. Em 1991, seis anos mais tarde, Roberto Medina atendeu aos inúmeros pedidos por um novo festival e levou para o estádio do Maracanã a segunda edição do Rock in Rio, reunindo 700 mil pessoas durante 9 dias. Essa edição garantiu a primeira visita do Guns N 'Roses ao Brasil. A banda fez dois shows históricos.

\footnotetext{
${ }^{3}$ A seção 3.1 usou como fonte, diversos sites que estão listados separadamente nas referências bibliográficas.
} 
Dez anos depois, no mesmo local onde Medina realizou o primeiro Rock in Rio, uma nova Cidade do Rock foi construída para a terceira edição do festival batizada de Rock in Rio - Por um Mundo Melhor. Roberto Medina viu no festival a melhor oportunidade de mobilizar pessoas e permitiu que parte do faturamento obtido com o Rock in Rio - Por um Mundo Melhor fosse destinada a projetos sociais. Graças à sua iniciativa, milhares de jovens de favelas e comunidades carentes do Rio de Janeiro puderam concluir os seus estudos. O Rock in Rio deixou de ser apenas um evento musical para se tornar o maior festival de música e entretenimento do mundo.

Em 2004, depois de se tornar referência mundial, foi a vez da Europa conhecer o festival que transformou o conceito de shows no Brasil. O Rock in Rio foi parar em Portugal e Lisboa onde ganhou a sua própria Cidade do Rock, onde sediou mais cinco edições, nos anos de 2006, 2008 e 2010, 2012 e 2014.

Após 10 anos sem o festival na cidade natal, em 2011, o Rock in Rio voltou e gerou tanta expectativa, que os 700 mil ingressos se esgotaram em quatro dias. Os sete dias de música e diversão que rolaram em setembro contaram com uma infraestrutura sem precedentes no Brasil. Foi assim que a quarta edição do Rock in Rio no Rio de Janeiro ficou mais uma vez na memória dos fãs e agora o festival promete repetir de 2 em 2 anos. Como se repetiu em 2013.

\subsection{Rock in Rio $2013^{4}$}

A edição de 2013 que aconteceu no mês de setembro teve seus ingressos esgotados em menos de quatro horas de vendas oficiais, e mais de 595 mil pessoas passaram pelo evento nos sete dias que trouxeram cantores internacionais, como Justin Timberlake, Beyonce, Slayer, John Mayer, Metallica, Bom Jovi, entre outros.

Por meio dos patrocinadores, o Rock in Rio consegue financiar de 50\% a $60 \%$ dos custos. Roberto Medina diz que o Rock in Rio não aconteceria, hoje, se não fosse pelo apoio dos patrocinadores. "Sem patrocínio, a conta não fecha." No festival, os patrocinadores criam experiências que vão além dos shows. "Temos de oferecer uma experiência completa, não só shows. Isso ajuda a criar memória afetiva no frequentador", afirma. Segundo Medina, é a memória afetiva que faz com que os visitantes queiram retornar nas edições seguintes, inclusive trazendo amigos e familiares para dividir a experiência.

Foram alguns patrocinadores oficiais, entre eles destaca-se o Club Social, CocaCola Zero, Heineken, Oi, Trident and Volkswagen e o Itaú como patrocinador máster.

\footnotetext{
${ }^{4}$ A seção 3.2 usou como fonte, diversos sites que estão listados separadamente nas referências bibliográficas.
} 
Entre eles as marcas Itaú, Heineken, Trident e Chilli Beans sediaram as quatro principais atrações, entre eles a roda gigante, a tirolesa, o turbo drop e a montanha russa, respectivamente.

Segundo estimativas da Secretaria de Turismo do Rio de Janeiro (Riotur), o Rock in Rio impactou em mais de $\mathrm{R} \$ 880$ milhões na economia do Rio de Janeiro, atingindo uma média de $90 \%$ de ocupação dos quartos da rede hoteleira carioca. $\mathrm{A}$ cidade contou com a visita de 350 mil turistas sendo $25 \%$ estrangeiros. 


\section{Métodos e procedimento de coleta e análise de dados do estudo}

Este capítulo pretende informar sobre a pesquisa que foi realizada baseada no estudo feito sobre o patrocínio do evento Rock in Rio 2013 por empresas privadas, com o objetivo de investigar e analisar como a marca Rock in Rio, agregou valor às marcas patrocinadoras do evento no ano de 2013 através do ponto de vista dos consumidores.

Foi dividido em cinco seções que informam, respectivamente, sobre as etapas de coleta de dados do estudo realizado, sobre o universo e amostras selecionadas para coleta de informações neste estudo. Na sequência, informa-se sobre os processos e instrumentos de coleta de dados realizados em cada etapa, com respectivas justificativas, sobre as formas escolhidas para tratar e analisar os dados coletados e, por fim, as implicações dessa escolha, assim como o que será feito com os resultados assim obtidos.

\subsection{Etapas de coleta de dados}

Esse estudo consiste de uma pesquisa quantitativa descritiva por meio de um questionário, elaborado, distribuído e analisado através da ferramenta Qualtrics.

Considerando que uma pesquisa descritiva tem como principal objetivo a descrição das características de determinada população, fenômeno ou estabelecimento de relações entre variáveis (GIL, 1999). Esta pesquisa pretende investigar e analisar como a marca Rock in Rio agregou valor às marcas patrocinadoras do evento no ano de 2013 através do ponto de vista dos consumidores.

\subsection{Universo e amostra}

No estudo em questão, o universo da pesquisa foi composto por pessoas com idades entre 18 e 35 anos que compareceram ao Rock in Rio 2013, na cidade do Rio de Janeiro. 
Os respondentes deste questionário foram selecionados pelo critério de acessibilidade, pois foram as pessoas que o pesquisador teve acesso e que se encaixavam no segundo critério de seleção, que foi a tipicidade, ou seja, que se adequavam ao perfil necessário. Teve como objetivo conseguir o maior número de respondentes possíveis, de forma a tentar conseguir dados relevantes que conseguisse evidências para pesquisas futuras.

Porém, o tamanho da amostra utilizada foi de 100 frequentadores do Rock in Rio 2013, por ter sido o máximo de respondentes que se propuseram a responder o questionário.

O processo de amostragem privilegiou amostra do tipo não probabilística, ou seja, o pesquisador utiliza como base elementos de amostra que lhe são acessíveis e ao mesmo tempo cooperativas, optando pela amostragem por conveniência, que é a técnica de amostragem que procura obter uma amostra de elementos conveniente, a seleção das unidades amostrais é deixada a cargo do pesquisador (MALHOTRA, 2006).

\subsection{Coleta de dados utilizados no estudo}

Para a realização da pesquisa descritiva, foi feita uma etapa que precedeu a distribuição do questionário, na qual foram realizadas entrevistas individuais com quatro colegas de trabalho do pesquisador que frequentaram o Rock in Rio 2013 e teve como objetivo definir quais seriam as melhores opções de abordagens nas perguntas fechadas do questionário e para verificar a adequação da linguagem e o entendimento das perguntas aplicadas.

Posteriormente, foi aplicado no mês de maio de 2015, o questionário com 12 perguntas fechadas e 2 abertas elaborado pelo software de pesquisa Qualtrics, que se encontra no Anexo 1 deste trabalho. Esta ferramenta gerou um link que foi distribuído para amigos e familiares do pesquisador e em um grupo de troca e venda de ingressos para o Rock in Rio 2015 que possui mais de dez mil membros, resultando em um total de 124 respostas, mas apenas 100 questionários puderam ser utilizados. As questões abordadas no questionário foram produzidas com base nos objetivos intermediários que pretende entender a percepção das pessoas que frequentaram o evento Rock in Rio 2013, na cidade do Rio de Janeiro em relação à marca Rock in Rio e seu impacto na visão quanto às marcas patrocinadoras.

Esse instrumento de coleta de dados foi escolhido por ser a maneira mais simples que o pesquisador encontrou de entrar em contato com uma grande 
quantidade de frequentadores do Rock in Rio 2013 e obter suas opiniões em relação ao tema de pesquisa.

\subsection{Tratamento e análise dos dados coletados para o estudo}

O presente estudo se utiliza da pesquisa descritiva, pois essa tem como objetivos descrever as características de grupos relevantes, além de estimar o percentual de pessoas desses grupos que possuem determinado comportamento, a fim de estabelecer associações entre eles e características de marketing (MALHOTRA, 2006). Assim, foi entendido como a melhor opção de pesquisa. A análise se limitou a frequência, média, moda, mediana e desvio padrão.

\subsection{Limitações do Estudo}

O presente trabalho pode sofrer algumas limitações em alguns momentos da pesquisa. É importante ressaltar que todo método de pesquisa tem limitações. Desta maneira, por delimitação, tem-se as fronteiras referentes a variáveis, ao que será abordado, ao corte, ao período de tempo e ao objeto de investigação (Vergara, 2010).

Assim, deve-se estar atento que a pesquisa quantitativa representa uma realidade reduzida às amostras e é preciso cuidado, já que pode não representar o todo.

Em primeiro lugar, por se tratar de um trabalho acadêmico, o tamanho da amostra permite uma margem de erro maior, assim como é possível que os dados da amostra não sejam suficientemente representativos da população como um todo, já que trata-se de uma amostra por conveniência, de tamanho um tanto ao quanto pequena. A maioria dos selecionados é de um círculo próximo entre amigos, familiares e colegas.

Também deve ser levado em consideração o comprometimento dos respondentes como uma limitação do estudo, pois alguns participantes podem não responder com sinceridade.

Sendo assim, foi importante que o pesquisador explicasse detalhadamente 0 objetivo da pesquisa e a importância da veracidade das respostas, a fim de evitar esses tipos de dificuldades, além de garantir que os respondentes entenderam de fato o propósito da pesquisa para não comprometer a qualidade das respostas. 
Outro fator importante que deve ser levado em consideração é que a pesquisa foi realizada 1 ano e 8 meses depois do Rock in Rio 2013. O que pode influenciar no recall de marca por parte dos frequentadores e por isso a resposta pode ser diferente do que se o questionário fosse aplicado logo após o evento.

Assim, o trabalho se propôs a investigar e analisar como a marca Rock in Rio, agregou valor às marcas patrocinadoras do evento no ano de 2013 através do ponto de vista dos consumidores. 


\section{Apresentação e Análise dos Resultados}

Este capítulo, organizado em seis seções, apresenta e discute os principais resultados alcançados, analisa e discute suas implicações e produz sugestões sobre o estudo previamente selecionado.

A primeira parte encontra-se a descrição da amostra, na qual serão divulgados os resultados do perfil dos respondentes do questionário como sexo, idade e estilos musicais que os respondentes mais gostam.

$\mathrm{Na}$ seção seguinte foi analisado o comportamento do consumidor em relação ao Rock in Rio 2013 e serão abordadas questões como os dias de festivais que os respondentes frequentaram motivos por ter frequentado e o que mais os incomodou no festival.

A terceira etapa aborda questões de associação à marca Rock in Rio, com perguntas fechadas e abertas.

Já na quarta seção foram feito perguntas sobre o patrocínio do Rock in Rio 2013, como a marca patrocinadora Top of Mind na visão dos consumidores, se eles concordam que o Rock in Rio é um bom lugar para expor uma marca e se estes se tornaram mais fiéis à alguma marca patrocinadora.

A seção seguinte aborda a questão dos entretenimentos oferecidos pelos patrocinadores e se os consumidores recordam quais marcas sediaram quatro, dos principais entretenimentos.

$E$, finalmente, na sexta parte foi analisado o ato da recompra, se quem frequentou o evento Rock in Rio 2013, voltaria em 2015. 


\subsection{Perfil dos respondentes}

A primeira pergunta sobre perfil questionava o sexo dos respondentes, exibido no Gráfico 1. Como podemos ver, a amostra possui mais pessoas do sexo feminino, representando $67 \%$ dos respondentes do que do sexo masculino, que são $33 \%$.

\section{Gráfico 1 - Perfil da amostra quanto ao sexo}

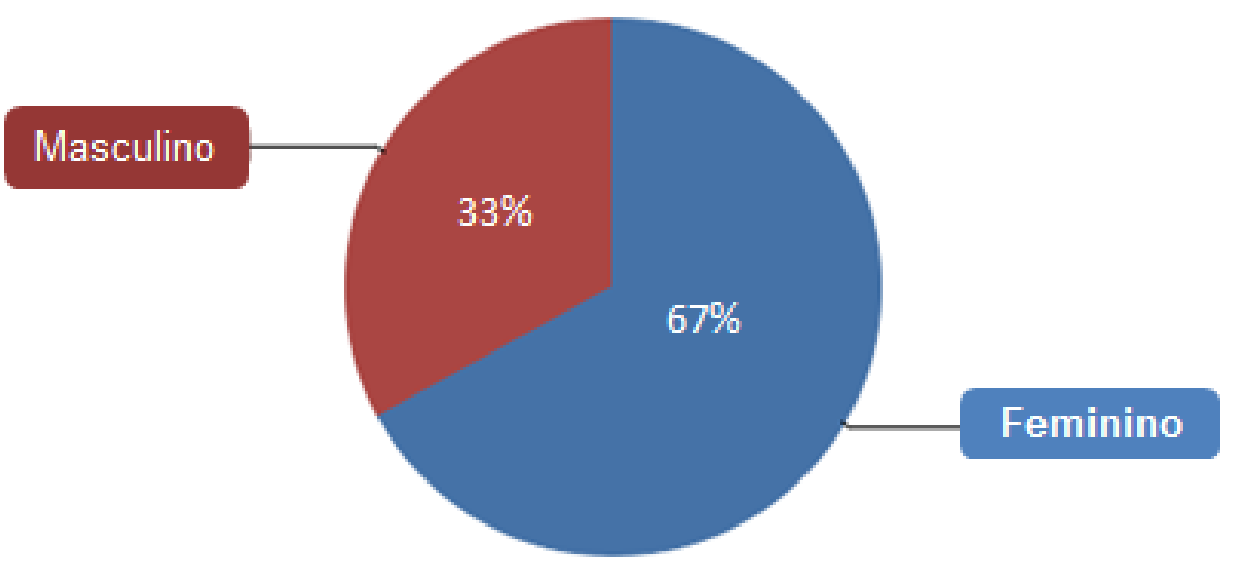

Em seguida, a pergunta foi sobre a idade dos respondentes e as opções de resposta para essa pergunta foram criadas com base no público-alvo do evento Rock in Rio.

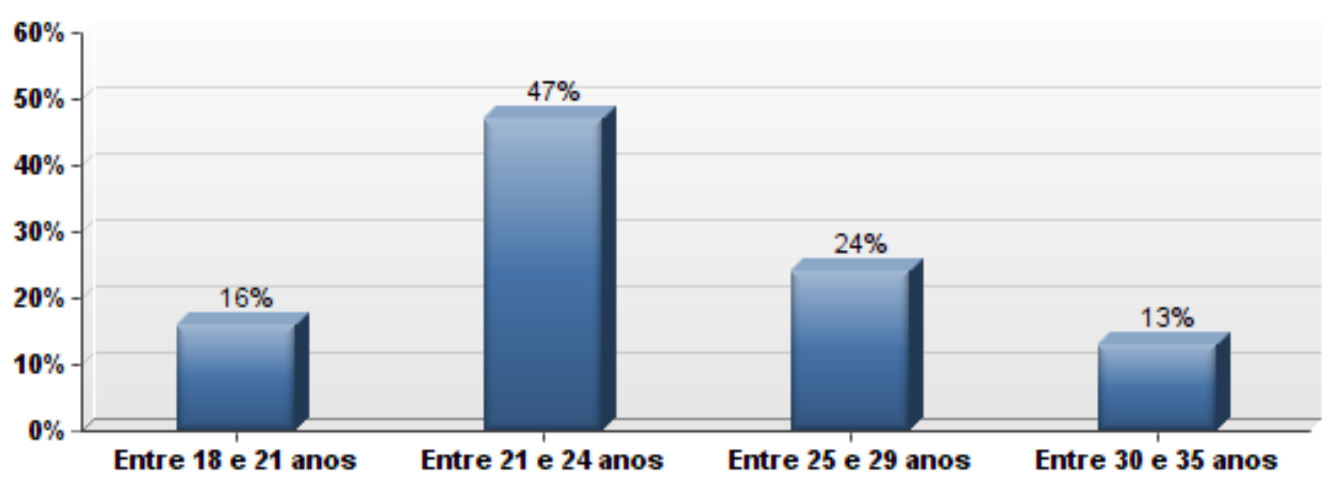

Figura 5 - Perfil da amostra quando à idade

Pelas respostas obtidas e ilustradas na Figura 5, percebe-se que as porcentagens referentes às idades de 21 a 24 anos representam a sua maioria (47\%), seguido de 25 a 29 anos (24\%), entre 18 e 21 anos representando 16\%, e por último entre 30 e 35 anos (13\%), respectivamente. É provável que este resultado seja 
explicado, pois o questionário foi distribuído através do Facebook em grupos de amigos/familiares do pesquisador, que são em sua maioria universitários.

Para finalizar o bloco de perguntas com o intuito de descrever o perfil da amostra, foi perguntado sobre o estilo musical que os respondentes mais se identificam. Roberta Medina, filha do fundador e idealizador do Rock in Rio, explica a importância do Rock in Rio, que é abranger a maioria dos estilos musicais:

\begin{abstract}
"Atrair essa quantidade de público só é possível com atrações muito populares, escolhidas por meio de pesquisas de mercado. Não há outra forma de vender quase 600000 ingressos que não seja trabalhando com conteúdo de massa. Temos de nos comunicar com públicos de todas as idades." (MEDINA, 2013) Disponível em: < http://veja.abril.com.br/noticia/entretenimento/rock-in-rio-um-caso-desucesso-em-um-mercado-em-crise/> Acessado em: maio/2015.
\end{abstract}

Isso explica, por exemplo, a presença do axé no festival, incômoda para roqueiros mais intransigentes, como podemos ver na figura 6 .

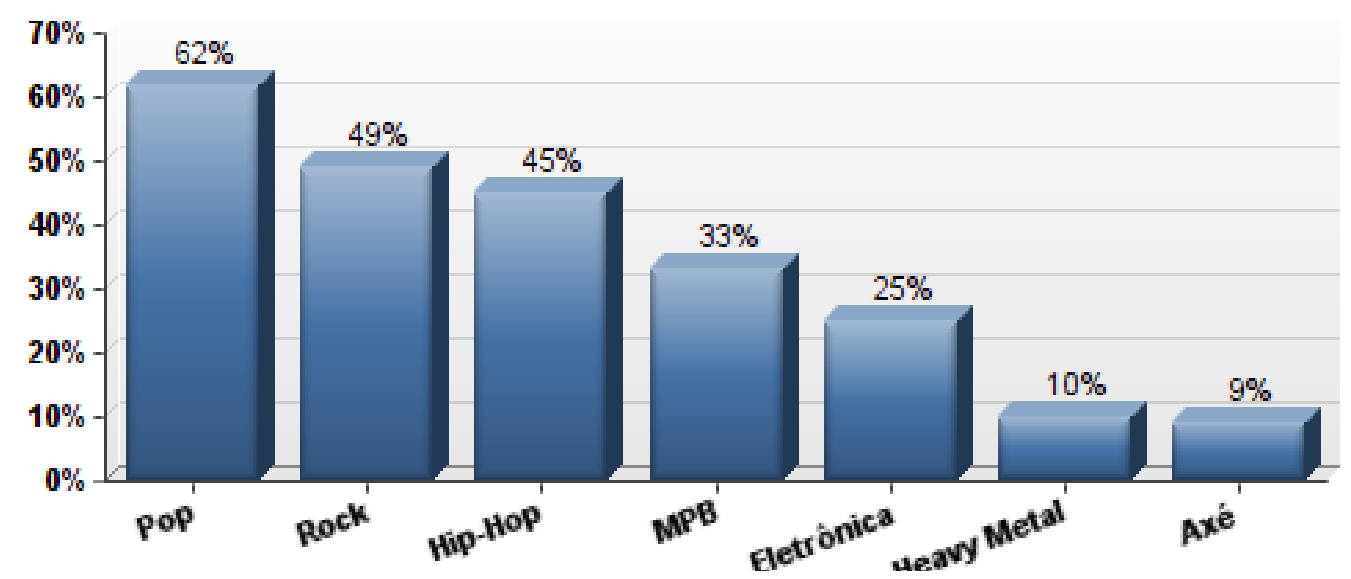

Figura 6 - Perfil da amostra do estilo musical que os respondentes mais gostam

Portanto, o perfil da amostra coletada nesta etapa da pesquisa é marcado por respondentes que possuem de 21 a 24 anos, do sexo feminino que curtem mais os estilos musicais: pop, rock e hip-hop. 


\subsection{Comportamento do consumidor em relação ao Rock in Rio 2013}

\subsubsection{Número de dias frequentados pelos respondentes}

A primeira pergunta desta etapa teve como objetivo saber quantos dias os respondentes frequentaram o festival Rock in Rio no ano de 2013 que ocorreu nos dias $13,14,15,19,20,21$ e 22 de setembro do mesmo ano.

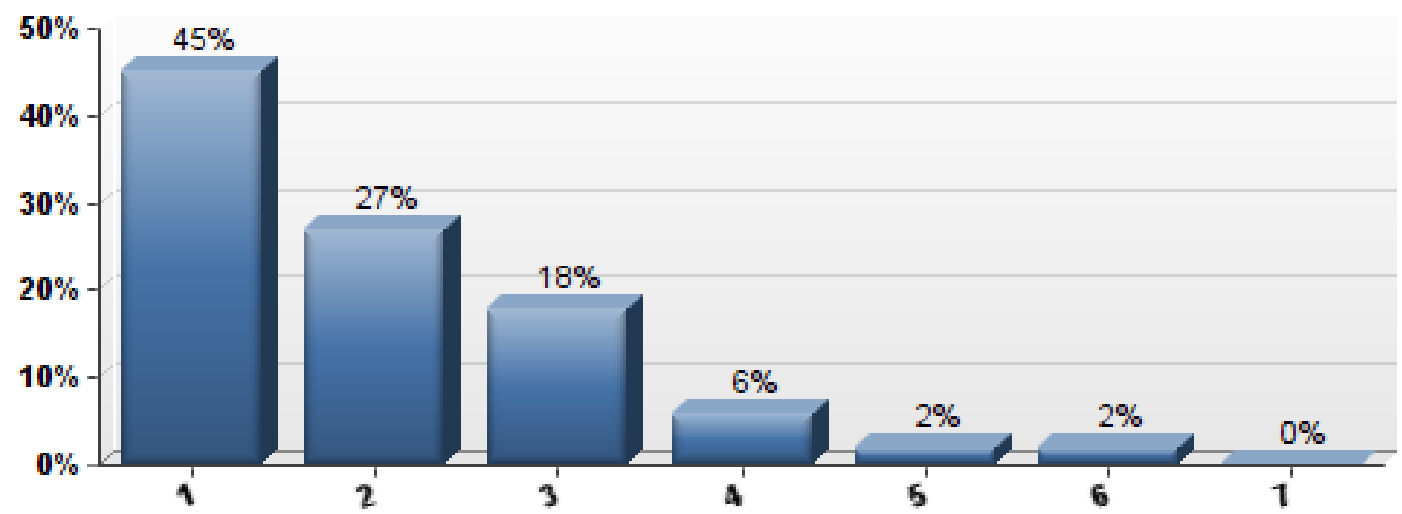

Figura 7 - número de dias frequentados no Rock in rio 2013

Pode-se observar na figura 7, que quase a maioria dos respondentes frequentou apenas um dia de festival, representando $45 \%$, porém somando quem esteve de dois a três dias no festival, totaliza também $45 \%$.

\subsubsection{Atributos que mais incomodou o público no Rock in Rio 2013}

Em seguida, o questionário abordou alguns atributos que mais incomodaram o público que frequentou o evento. Os atributos eram: falta de estacionamento, multidão, alimentação, trajeto para chegar ao local do festival, e alto valor dos ingressos. Os respondentes deviam dar uma nota a cada atributo de 1 a 5 , sendo 1 a que menos incomodou e 5 para o atributo que mais incomodou.

Conforme analisado na tabela 1, o atributo que menos causou desconforto do público respondente foi a falta de estacionamento no local do evento, com $37 \%$. Apesar da maioria, 54\% de rejeição, terem indicado o alto valor dos ingressos como o que mais incomodou, para $29 \%$ dos respondentes, este item foi o que menos incomodou. 
A alimentação no local do evento também foi um ponto criticado, mas mesmo assim foi o item que teve o maior percentual de nota 5, 29\%. A multidão e o trajeto para chegar ao local do evento tiveram as notas muito bem distribuídas, pois os extremos, 1 e 2 e 4 e 5 tiveram frequências acumuladas bem próximas.

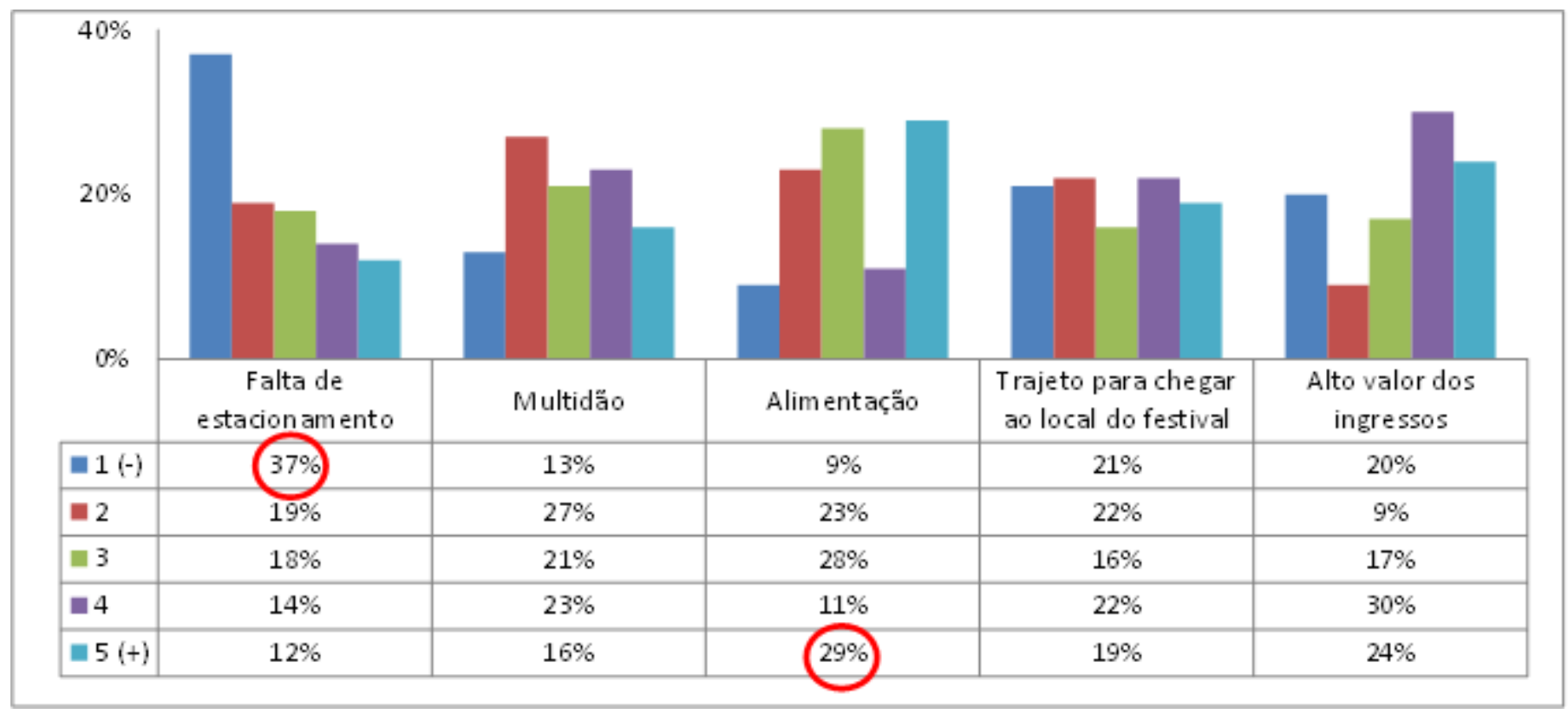

Tabela 1 - Atributos que mais incomodaram o público no Rock in Rio 2013

\subsubsection{Motivos por ter frequentado o Rock in Rio 2013}

Por fim, ainda abordando o comportamento dos consumidores em relação ao Rock in Rio 2013, foi perguntado aos respondentes quais as maiores motivações que os levaram a frequentar o festival. Podemos analisar através da Figura 8 que por mais que o Rock in Rio não seja apenas um show, mas sim um festival internacional, que traz atrações e entretenimentos ao público, o motivo que teve mais destaque, com $82 \%$, ainda é para ver as bandas/cantores que se apresentam.

Porém, é possível analisar que o público também possui interesse em conhecer o festival e ver as atrações que são oferecidas, com $25 \%$ e $26 \%$ respectivamente. 


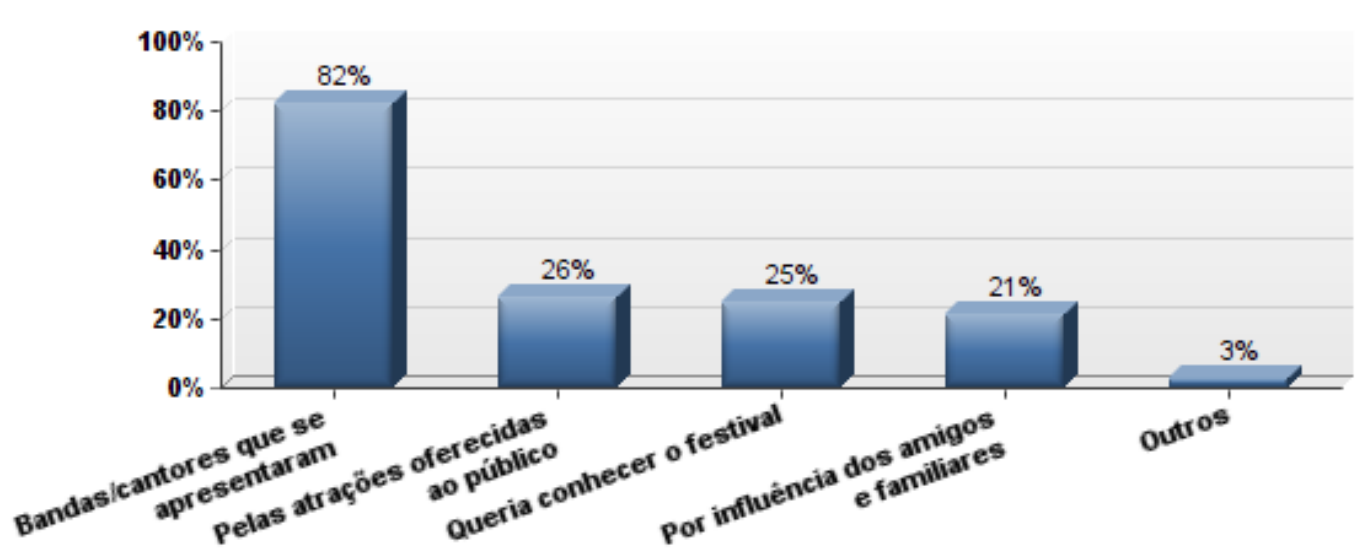

Figura 8 - Motivos por ter frequentado o Rock in Rio 2013

\subsection{Associação à marca Rock in Rio}

\subsubsection{Associação espontânea}

A primeira questão sobre associação à marca Rock in Rio, foi uma pergunta aberta na qual os respondentes podiam escrever a primeira característica que lhes vinham à cabeça ao pensar na marca Rock in Rio. Das 100 respostas, apenas um não entendeu a pergunta, outros três deram as características negativas, como perrengue, bagunça e lorota, mas em sua maioria, como podemos ver na figura 9, as associações foram positivas.

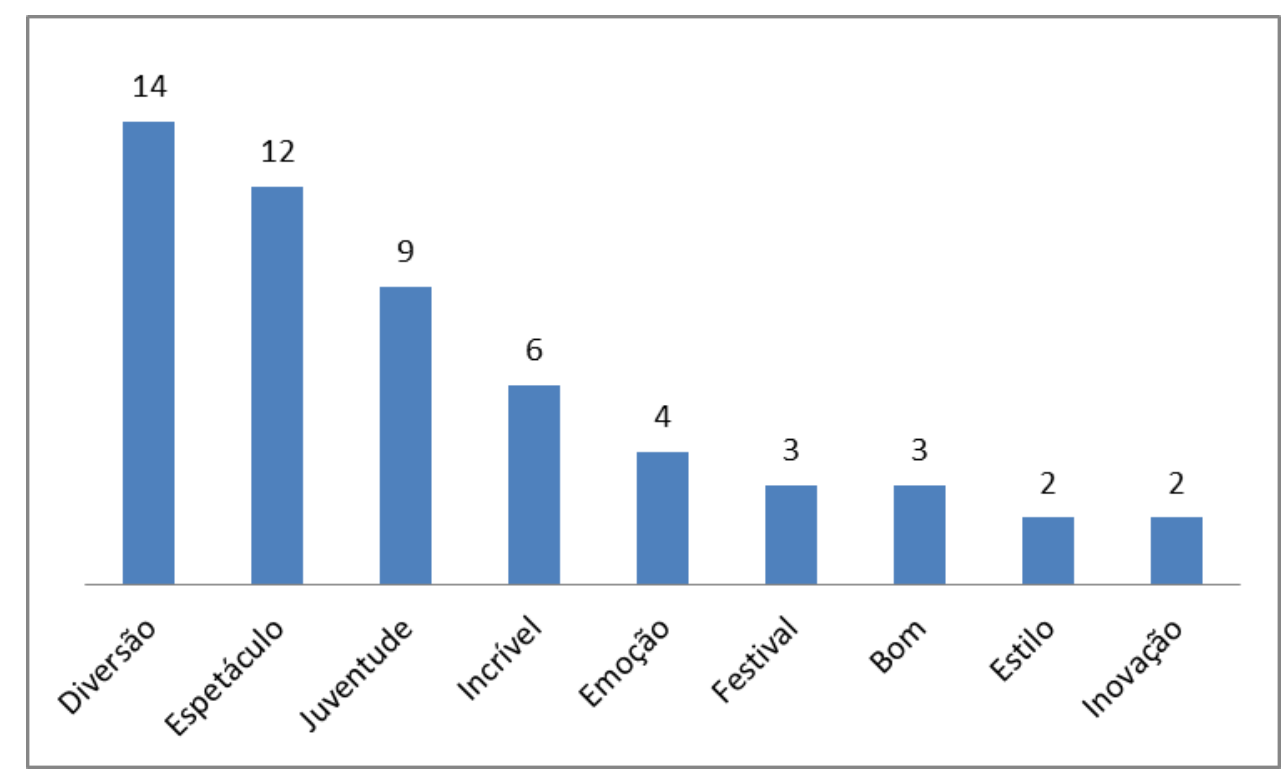

Figura 9 - Associação espontânea à marca Rock in Rio 


\subsubsection{Associação a partir de uma lista dada}

A segunda pergunta com relação à associação a marca do Rock in Rio por parte dos frequentadores do evento foi uma pergunta fechada a partir de uma lista dada com algumas características positivas e negativas. Podemos notar que as caraterísticas positivas tiveram uma importância muito mais relevante que as negativas ${ }^{5}$. A porcentagem representa a quantidade de respondentes por característica em relação ao total dos entrevistados (100 pessoas).

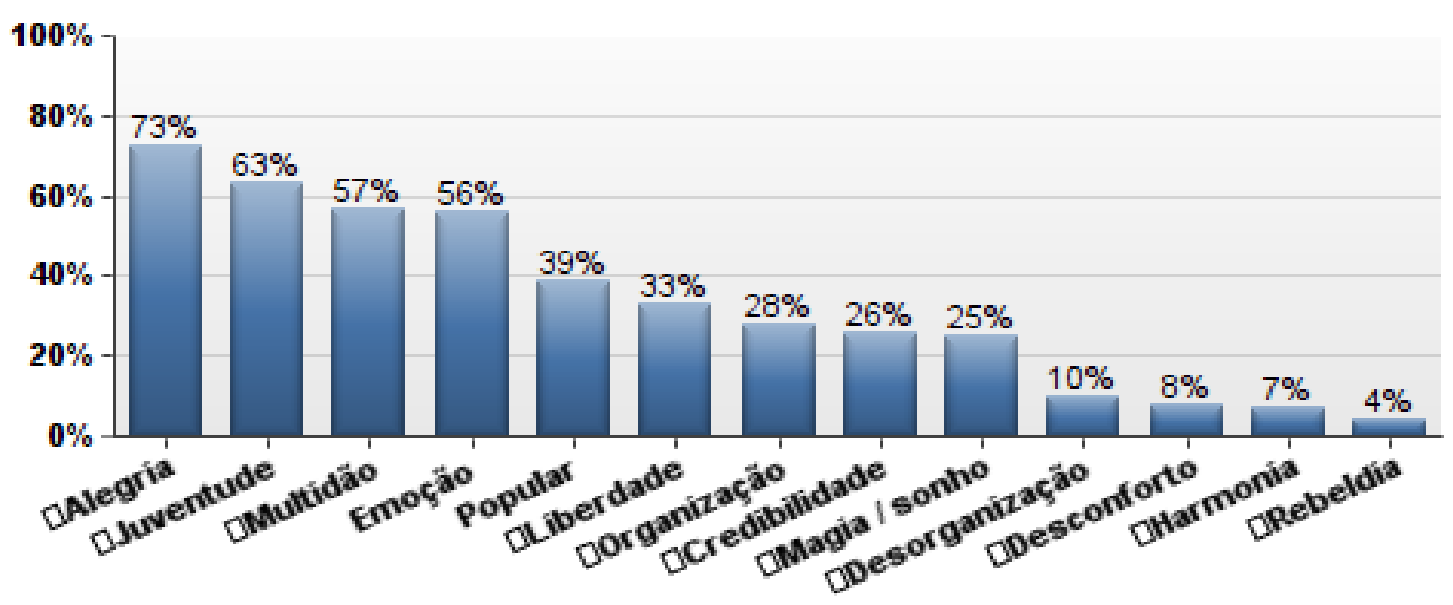

Figura 10 - Associação à marca rock in rio, a partir de uma lista dada

\subsection{Marcas patrocinadoras}

\subsubsection{Lembrança de marca (Top of Mind)}

Um ponto a ser destacado é que a marca de telefonia Oi, patrocinadora oficial do Rock in Rio 2013, escolheu o maior festival de música e entretenimento como cenário para realização de ações diretas com o público-alvo, como o lançamento oficial de um novo plano, o Oi Galera, com a distribuição de 30 mil unidades de chips. Os clientes que passaram a fazer parte do Oi Galera durante o evento poderiam convidar, na hora, cinco amigos do Facebook para aderir ao plano.

\footnotetext{
${ }^{5}$ Nota-se que as respostas somam mais que $100 \%$, visto que era permitido marcar mais de uma característica.
} 
O intuito dessa campanha era fortalecer o posicionamento da marca neste segmento, já que a companhia é a primeira marca que vem à cabeça (top of mind) de jovens entre 18 e 25 anos, segundo pesquisa realizada pela própria marca ${ }^{6}$.

Porém, como podemos ver na figura 11, quando a pergunta aberta foi: "Qual a primeira marca que vem à sua cabeça quando se lembra do festival Rock in Rio 2013" a marca só representou $1 \%$ de lembrança dentre os entrevistados. O que pode ser devido ao fato que o público não aderiu ao plano Oi Galera, ou pelo fato de que $30 \mathrm{mil}$ unidades não foi o suficiente para distribuir em um festival que compareceram 595mil pessoas.

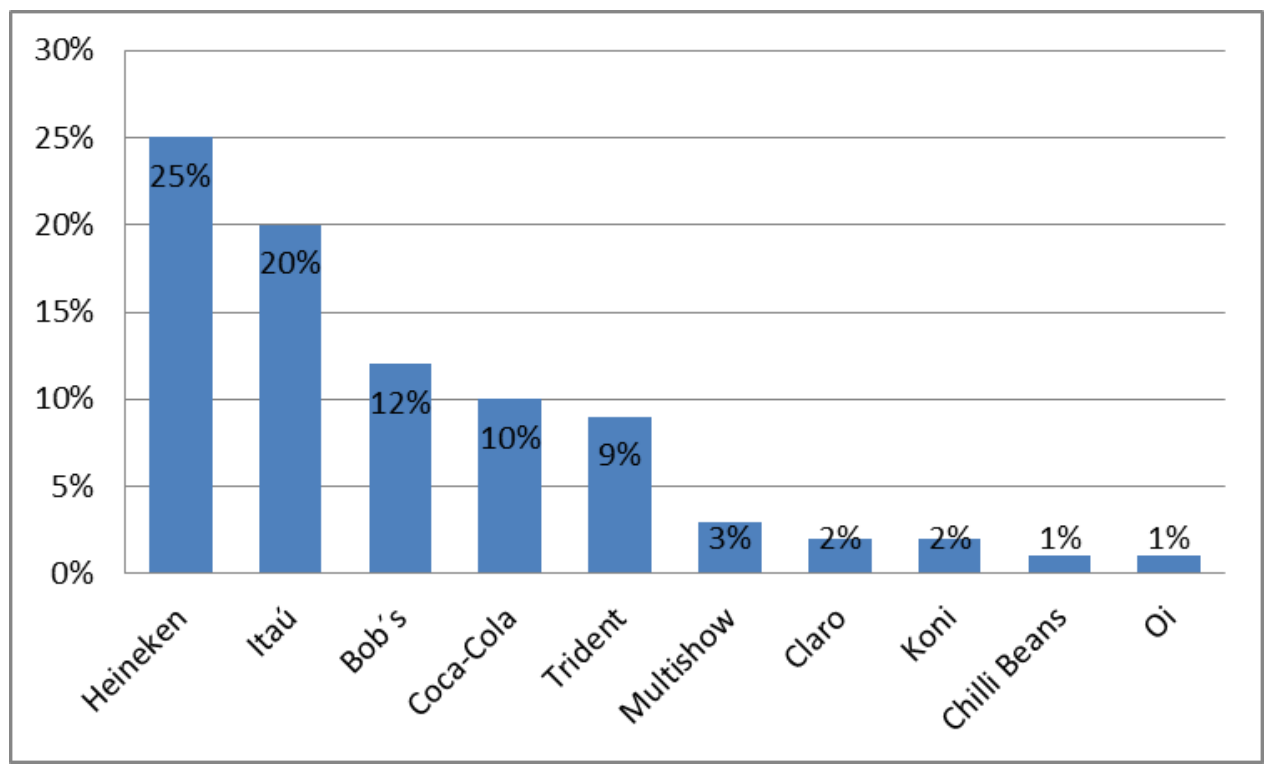

Figura 11 - Primeira marca patrocinadora a ser lembrada (Top of Mind)

Em seguida, o questionário abordou em formato de pergunta fechada, quais marcas patrocinaram o evento. Foi dada uma lista com 24 marcas, e dentre essas marcas algumas não tinham sido patrocinadoras.

Podemos perceber, pela figura 12, que a marca mais lembrada foi o Bob's, o que não necessariamente é uma lembrança de marca positiva, uma vez que o Bob's recebeu diversas críticas em matérias depois do evento ${ }^{7}$, por ser acusado de se

\begin{tabular}{llllll}
\hline 6 & Pesquisa & realizada & pela & disponível & em
\end{tabular} http://exame.abril.com.br/negocios/releases/oilancaestrategiaparaconquistarpublicojovem.shtml> Acesso em maio/2015.

7 Disponível em: <http://reporterbrasil.org.br/2013/12/bobs-usou-trabalho-escravo-durante-o-rock-in-rio-apontafiscalizacao/> e <http://ultimosegundo.ig.com.br/rockinrio/precos-altos-irritam-frequentadores-do-rock-inrio/n1597226027349.html> Acesso em maio/2015. 
aproveitar do trabalho escravo durante o festival e também pelo alto e abusivo valor nos seus lanches.

Como podemos ver na Figura 12, uma questão relevante é que as outras quatro marcas a serem mais lembradas, Heineken, Itaú e Trident e Chilli Beans, representando $84 \%, 69 \%, 63 \%$ e $46 \%$, respectivamente foram as marcas que sediaram as grandes atrações abordadas na seção 4.5. O que se deve ao fato que 0 público pode ter apresentado uma associação positiva quanto a essas marcas.

Outra questão importante é que das 24 marcas patrocinadoras, 6 marcas não patrocinaram, foram elas: Mc Donalds, Domino`s, Guaraná, Brahma, Gol e Fiat, sendo que cinco dessas marcas tiveram lembrança de ter patrocinado, como podemos ver no caso da Dominos que teve $37 \%$ de lembrança.

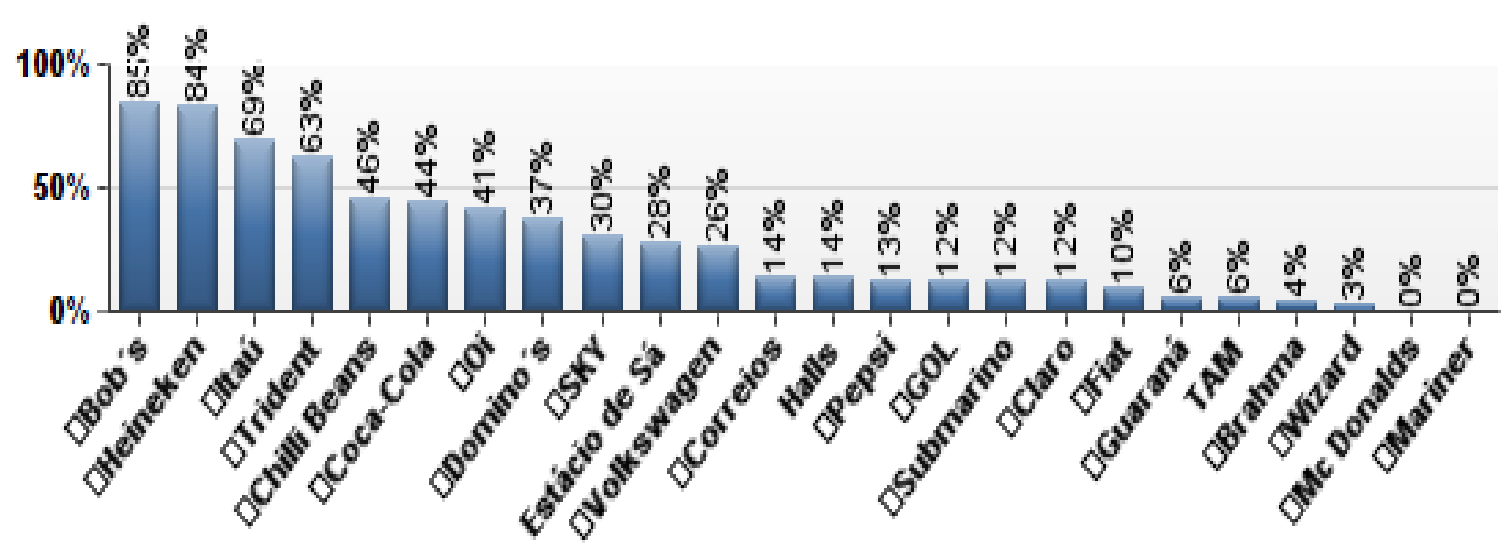

Figura 12 - Lembrança das marcas patrocinadoras

\subsubsection{O festival Rock in Rio como evento para exposição das marcas}

Outra pergunta desta etapa ainda em relação ao patrocínio da marca Rock in Rio, concluiu que $80 \%$ dos respondentes concordam que o Rock in Rio é um evento ideal para a exposição das marcas, contra $20 \%$ que não concordam.

Outro item abordado foi se os frequentadores julgam que se tornaram mais fiéis às marcas patrocinadoras após o evento, $89 \%$ julgaram que não e apenas $11 \%$ concordam que se tornaram mais fiéis às seguintes marcas: Itaú (3); Heineken (2); Chilli Beans; Volkswagen; Trident; Bob's; Koni; e Oi. 


\subsection{Experiência de marca oferecido pelas marcas patrocinadoras}

Os quatro principais entretenimentos da edição de 2013 foram a Roda Gigante Itaú, Tirolesa Heineken, Turbo Drop Trident, Montanha Russa Chilli Beans que somaram um total de $90,9^{8}$ mil pessoas que puderam usufruir das atividades paralelas na Cidade do Rock.

A questão apresentou as quatro principais atrações, e em formato de pergunta aberta foi pedido que os respondentes escrevessem quais marcas patrocinaram. Como podemos ver na figura 13 , a maioria dos respondentes (48\%) acertou que foi o Itaú que sediou a roda gigante.

Isso também ocorreu na figura 14, onde mais do que a maioria dos respondentes $(52 \%)$ acertaram que foi a Heineken que sediou a Tirolesa, isso pode ser pelo fato de que essa atração ficava em frente ao palco mundo, palco principal do evento. Além do que a Heineken era a única cervejaria patrocinadora e ao longo dos sete dias de evento, a empresa vendeu 700 mil litros de chopp na Cidade do Rock. Ao total, foram 1,7 milhão de copos vendidos. $^{9}$

Na figura 15, podemos notar que o mesmo número de pessoas que disseram ter sido a marca de óculos Chilli Beans que patrocinou a Montanha Russa, foi o mesmo número de respondentes que não lembrava. O que pode ser pelo fato que era uma atração isolada do palco mundo ou pelo fato de que o público não associa a marca à aventura, no caso de atração como uma montanha russa.

O mesmo fato pode ter ocorrido com a marca Trident que apenas 33\% dos respondentes associaram a marca à atração Turbo Drop, que também foi uma atração que ficou distante do palco principal, como pode ser visto na Figura 16.

\footnotetext{
8 Disponível em: <http://rockinrio.com/infografico2013/> Acesso em 15 de abril de 2015.

${ }^{9}$ Disponível em: <http://rockinrio.com/infografico2013/> Acesso em 15 de abril de 2015.
} 


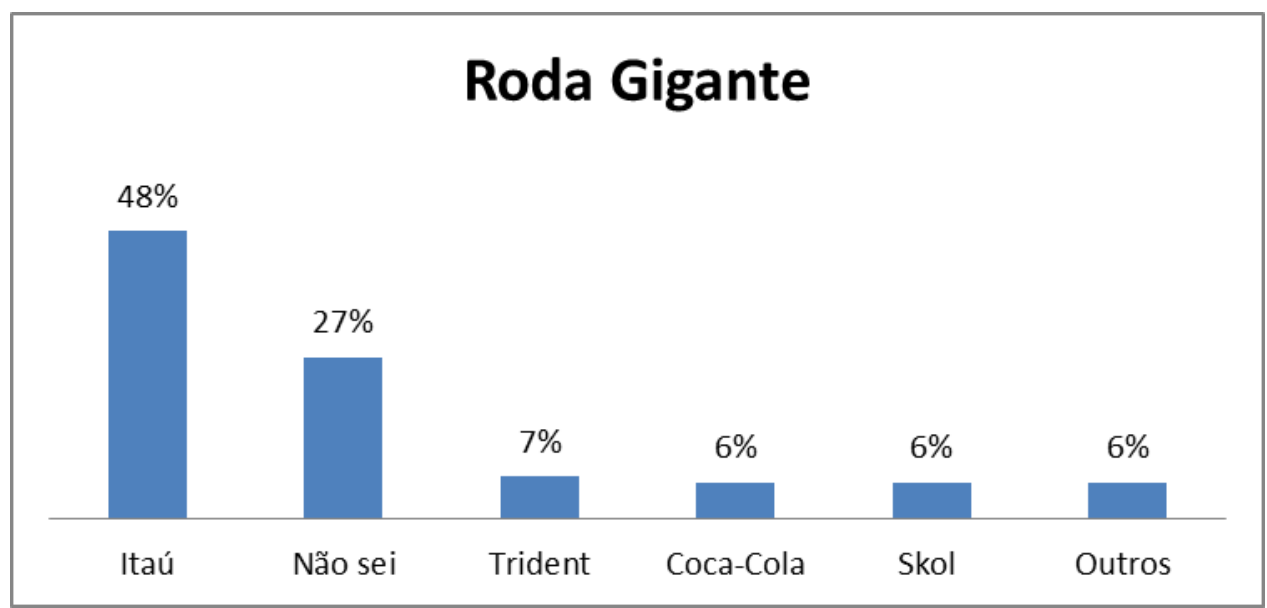

Figura 13 - Roda Gigante oferecida pela marca Itaú

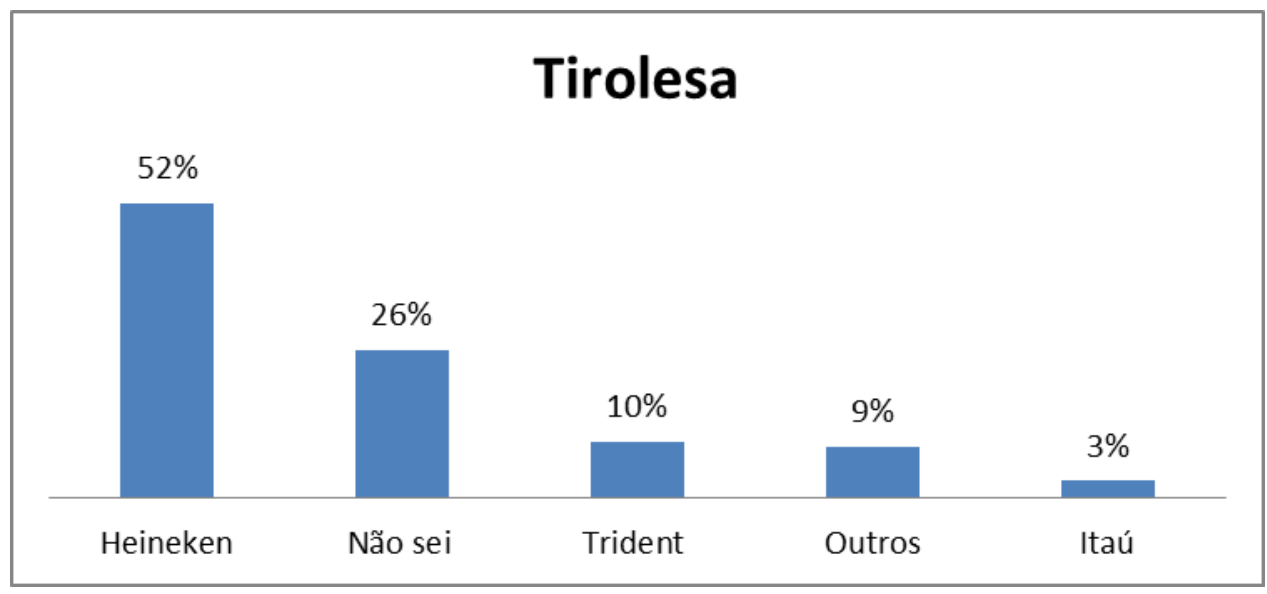

Figura 14 - Tirolesa oferecida pela marca Heineken

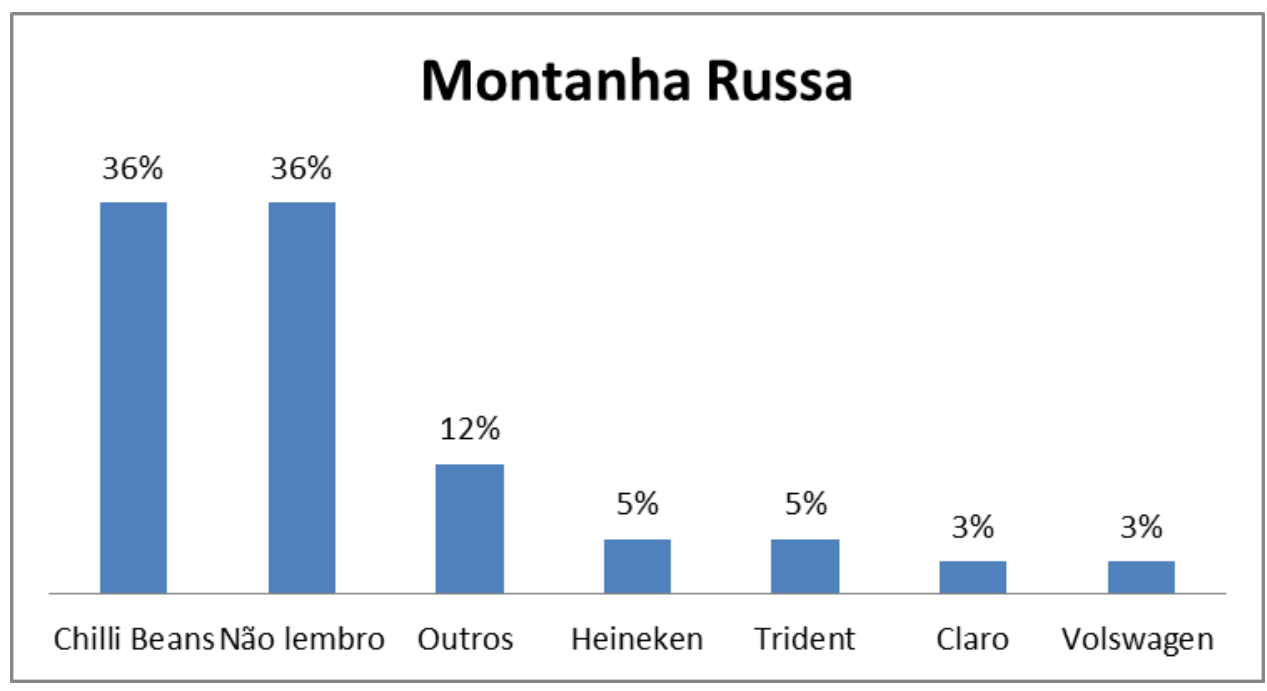

Figura 15 - Montanha Russa oferecida pela marca Chilli Beans 


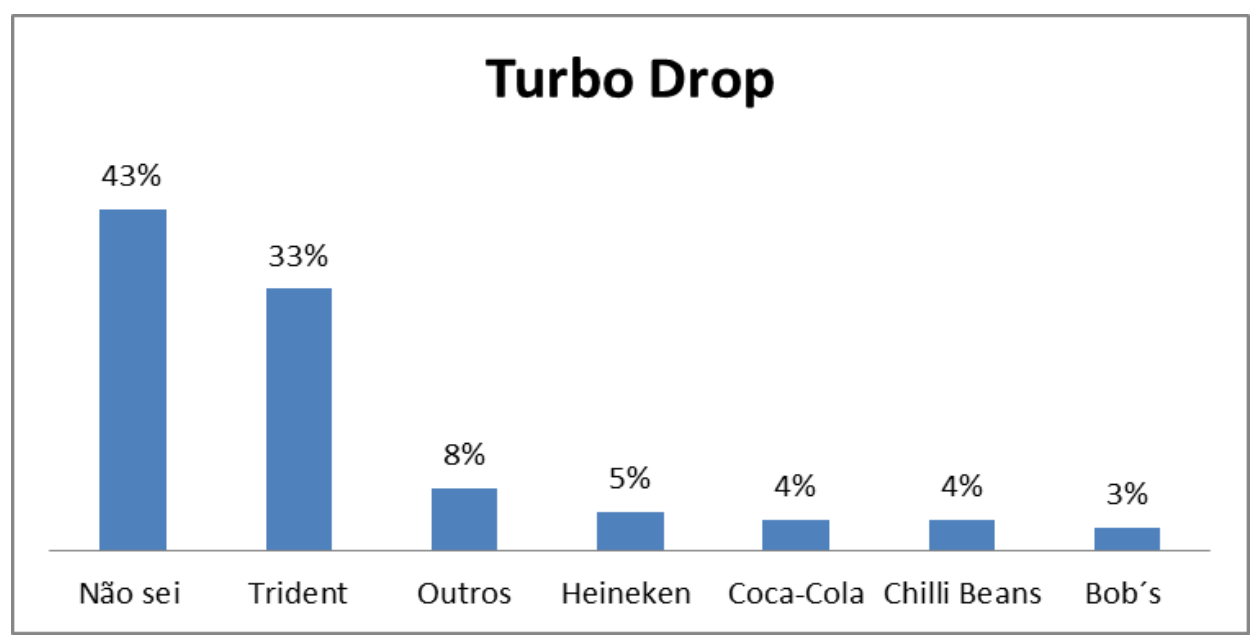

Figura 16 - Turbo Drop oferecido pela marca Trident

\subsection{Recompra do evento Rock in Rio}

O último item do questionário aborda a questão de recompra do evento, podemos notar que uma boa parte dos respondentes (34\%) pretende ir à edição do Rock in Rio 2015, porém 30\% diz que depende das bandas, o que pode ser devido ao fato que já foi divulgado alguns dias de shows e houve críticas. Outra grande proporção (27\%) diz que não iria com certeza.

Apenas $9 \%$ dos respondentes disseram que depende do quesito preço. Esta baixa porcentagem mostra que há uma certa inelasticidade quanto ao valor dos ingressos. O que pode ser devido ao fato que os organizadores do festival procuram manter um valor de ingresso acessível, como afirma Roberta Medina, filha do empresário e fundador do Rock in Rio.

"Desde quando o festival começou, em 1985, sabia-se que ele precisaria ser grande, porque o poder aquisitivo da população na época era pequeno e os ingressos não poderiam ser caros. Então, era preciso vender muitos bilhetes para compensar". Até hoje, tentamos manter um valor de ingresso acessível (MEDINA,2013) Disponível em: < http://veja.abril.com.br/noticia/entretenimento/rockin-rio-um-caso-de-sucesso-em-um-mercado-em-crise/> Acessado em: maio/2015. 


\section{Conclusões e recomendações para novos estudos}

Este trabalho pretendeu investigar e analisar como a marca Rock in Rio, agregou valor às marcas patrocinadoras do evento no ano de 2013 através do ponto de vista dos consumidores. Também pretendeu levantar como os consumidores percebem os benefícios em relação às marcas que patrocinaram o Rock in Rio 2013 em termos de conhecimento, associações e qualidade e lealdade e se aumentou o envolvimento deles com as essas marcas.

Tais questões se mostram importantes na medida em que há um crescimento no mercado de patrocínios e eventos e o Rock in Rio se tornou um festival de exposição de marcas que atrai o público não apenas pelos shows, mas pelas experiências que o festival em si traz ao seu público.

Para aprofundar a análise pretendida, investigou-se primeiramente sobre a marca, e o envolvimento com a mesma, conceitualizando e mostrando a visão de autores como o Tavares (2003), Roberts (2005), Pinho (1996), Aaker (1998), Kotler e Keller (2006 e 2012) e Solomon (2002).

Posteriormente foi conceituado o brand equity através de diferentes perspectivas de autores como Pinho (1996), Strunk, (2001), Kotler e Keller (2006), Aaker (1998) e Cobra (2014). Foram adotadas, neste estudo, as quatro dimensões do brand equity criadas pelo pesquisador e estudioso do assunto, David Aaker (1998), quais sejam: lealdade à marca, conhecimento da marca, qualidade percebida, associações da marca e outros ativos da empresa. Ainda em relação ao brand equity, foram analisados o valor que o mesmo agrega aos clientes e às empresas.

Em seguida, foi estudado o patrocínio de eventos na visão dos autores Costa (2004), Melo Neto (2000), Pope e Voges (1999), (Aaker, 1998) e Kotler e Keller (2006). Por fim foi também analisado o marketing de experiência através da visão dos autores Schmitt (2000) e Kotler e Keller (2012).

Para atingir os objetivos pretendidos foi realizada uma pesquisa descritiva a partir de um questionário aplicado ao público que frequentou o Rock in Rio no ano de 2013 para investigar a percepção deles em relação às marcas patrocinadoras da edição, o qual contou com 14 questões e atingiu uma amostra de 124 respondentes, mas apenas 100 puderam ser utilizados. Este questionário foi distribuído através de 
um link gerado pelo software de pesquisa Qualtrics para amigos e familiares do pesquisador e para um grupo do evento Rock in Rio no facebook.

Através dos resultados obtidos nos questionários, foi possível verificar que os consumidores percebem a marca Rock in Rio como uma marca jovem, associada à diversão, emoção, liberdade, organização, credibilidade, magia/sonho, espetáculo, inovação (...) e apenas uma minoria associou a marca a alguma característica negativa. Portanto, o primeiro objetivo intermediário foi alcançado.

Em relação ao segundo e ao terceiro objetivos intermediários, o benefício percebido pelos consumidores em relação às marcas que patrocinaram o Rock in Rio 2013 em termos de conhecimento, associações, qualidade e lealdade, foi visto que as marcas que sediaram as grandes atrações do festival, como Heineken, Itaú, Trident, foram as mais lembradas pelo público, e que os respondentes não tiveram dificuldade em lembrar as marcas patrocinadoras. Mas o interessante foi que a marca Bob's também teve uma lembrança alta, porém foi uma marca que recebeu críticas pelo serviço que foi prestado no festival.

Além disso, o serviço de alimentação foi o que teve o maior percentual de rejeição, nos atributos que geraram desconforto ao público.

Outra análise que pode ser feita é investigar se aumentou o envolvimento dos consumidores com as marcas patrocinadoras e se houve alguma alteração na imagem dessas marcas por parte do público que compareceu ao Rock in Rio 2013, concluindo dessa forma o quarto objetivo intermediário. A pesquisa informou que a maior parte dos respondentes concorda que o Rock in Rio é um evento ideal para exposição das marcas, mas apenas uma parte deles se tornou mais fiel á alguma marca patrocinadora.

\subsection{Sugestões e recomendações para novos estudos}

Como desdobramentos futuros, essa linha de estudo pode ser desenvolvida através de uma maior investigação sobre a internacionalização da marca Rock in Rio, para a Europa, onde o festival ocorreu na cidade de Lisboa nos anos de 2004, 2006, 2008, 2010, 2012, 2014; em Madrid, na Espanha nos anos de 2008, 2010 e para os Estados Unidos, onde ocorreu pela primeira vez no mês de maio de 2015, na cidade de Las Vegas, conhecida por sediar grandes shows do mundo inteiro.

Além disso, seria interessante também fazer uma análise mais profunda sobre quais são as razões da marca ter se internacionalizado e a percepção e aceitação por 
parte do público europeu e americano em relação ao festival Rock in Rio e suas marcas patrocinadoras.

O estudo em questão tratou apenas do festival de 2013. Para próximos estudos, seria interessante uma comparação do primeiro Rock in Rio em 1985, quando o festival tinha um foco mais musical, com a edição mais recente, que tem um apelo mais comercial, e busca não apenas entreter o público com seus grandes shows, mas também fornecer uma experiência completa com as atrações que são oferecidas pelas marcas patrocinadoras.

Por fim, considerando que o estudo tratou apenas da percepção por parte dos consumidores em relação à marca, pode-se avaliar também, a percepção que as empresas patrocinadoras tiveram em relação ao retorno de branding com o evento. 


\section{Referências Bibliográficas}

AAKER, David. Marcas. Brand Equity - Gerenciando valor à marca. 3 ed. São Paulo: Negócio, 1998.

AAKER, David. The Value of Brand Equity. Journal of Business Strategy, v.13, n.4, p.27-32, (1992).

BEZERRA, Beatriz Braga. Patrocínio de Eventos: Ferramenta Estratégica de Comunicação e Vendas. Recife, 2011. Monografia (Pós-graduação em Gestão da Comunicação Empresarial) - Faculdade Frassinetti do Recife.

BOWDIN, Glenn A. J; ALLEN, Johnny; O'TOOLE, William; HARRIS, Rob; MCDONNELL, Ian. Events Management. Great Britain: John Wiley \& Sons Australia Ltd, 2006.

CARNEIRO, Luis Felipe. Rock in Rio: A Historia do Maior Festival de Musica do Mundo. São Paulo: Globo, 2011.

CHULAM, Filipe Fernandes. Estudo de Caso sobre a Internacionalização da Marca Rock in Rio e sua repercussão no Publico do Rio de Janeiro. Rio de Janeiro, 2004. Monografia (Graduação em Administração de Empresas)- Departamento de Administração: Pontifícia Universidade Católica do Rio de Janeiro.

COBRA, Marcos. Serviços: Como construir valor para o cliente. São Paulo: Marcos Sobra, 2014.

COSTA, Ivan. Marketing Cultural. São Paulo: Atlas, 2004.

GIL, Antônio. C. Métodos e Técnicas de Pesquisa Social. São Paulo: Atlas, 1999. 
GOMES, Thiago. Rock in Rio 2013 - Business in Numbers. Bric Expansion, Rio de Janeiro 13 outubro 2013. Disponível em: <http://www.bricexpansion.com/rock-in-riobusiness-numbers/> Acesso em: 27 de novembro 2014.

MALHOTRA, Naresh. Pesquisa de marketing: uma orientação aplicada; tradução Laura Bocco. Porto Alegre: Bookman, 2006.

MELO NETO, Francisco P. de. Marketing de Patrocínio. Rio de Janeiro: Sprint, 2000.

KOTLER, Philip.; KELLER, Kevin L. Administração de Marketing. 12ª Ed. São Paulo: Pearson Prentice Hall, 2006

KOTLER, Philip.; KELLER, Kevin L. Administração de Marketing. Editora Prentice Hall. Tradução da 14ª Edição Norte-Americana, 14ª Edição Brasileira. São Paulo, 2012

PINHO, José B. O Poder das Marcas. São Paulo: Summus, 1996.

POPE, N K.; VOGES K.E. Sponsorship and Image: A replication and extension. Journal of Marketing Communications, v.5, n.1 p. 17-28, (1999).

ROBERTS, Kevin. Lovemarks, O Futuro Além das Marcas. São Paulo Saatchi \& Saatchi, 2005.

SOLOMON, Michael. R. O Comportamento do consumidor: Comprando, Possuindo e Sendo. 5⿳ㅗ Ed. Porto Alegre, Bookman, 2002.

SCHMITT, Bernd H. Experiential Marketing: How to Get Customers to Sense, Feel, Think, Act, Relate to your Companies and Brands. New York: Free Press, 2000.

STRUNCK, Gilberto. Como criar identidades visuais para marcas de sucesso. Rio de Janeiro: Rio Books, 2001.

TAVARES, Fred. Gestão de Marca. Rio de Janeiro: e-papers Serviços Editoriais, 2003. 
TAVARES, Mauro Calixta. A Força da Marca. Como Construir e Manter Marcas Fortes. São Paulo : Harbra, 1998.

VERGARA, Sylvia. C. Projetos e Relatórios de Pesquisa em Administração. São Paulo: Atlas, 2010.

Rock in Rio: um show de ativação. Disponível em: <http://promoview.com.br/acaopromo/146137-rock-in-rio-um-show-de-ativacao/> Acesso em 14 de novembro de 2014.

Fontes usadas nas seções 3.1 e 3.2:

MACEDO, Rosayne. Megaespetáculo de interação entre marcas e consumidores. Rio de Janeiro 22 de setembro de 2011 <http://www.meioemensagem.com.br/home/marketing/noticias/2011/09/22/Megaespet aculo-de-interacao-entre-marcas-e-consumidores.html Acesso em 14 de abril de 2015> Acesso em 14 de abril de 2015.

NOGUEIRA, Carol. Rock in Rio, um caso de sucesso em um mercado em crise. Rio de Janeiro 08 de setembro de 2013. Disponível em: $<$ http://veja.abril.com.br/noticia/entretenimento/rock-in-rio-um-caso-de-sucesso-em-ummercado-em-crise/> Acesso em 14 de abril de 2015.

Infográfico do Rock in Rio 2013. Disponível em <http://rockinrio.com/infografico2013/> Acesso em 15 de abril de 2015.

Rock in Rio: mais do que atrações, um festival de negócios. Rio de Janeiro 05 de setembro de 2013. Disponível em: <http://bahiaprime.com.br/mercado/rock-in-rio-maisdo-que-atracoes-um-festival-de-negocios.html> Acesso em 14 de abril de 2015. 


\section{Anexo 1}

Questionário aplicado na pesquisa descritiva:

Esse questionário foi elaborado a fim de entender como a marca Rock in Rio, agregou valor às marcas patrocinadoras do evento no ano de 2013 através do ponto de vista dos consumidores. Por esse motivo, ele deverá ser respondido por homens e mulheres com idades entre 18 e 35 anos que compareceram ao festival Rock in Rio no ano de 2013.

Muito obrigada pela compreensão e ajuda!

Q1 Qual o seu gênero?

O Feminino

O Masculino

Q2 Qual a sua idade?

O Entre 18 e 21 anos

O Entre 21 e 24 anos

O Entre 25 e 29 anos

O Entre 30 e 35 anos

Q3 Marque as três opções de estilos musicais que você mais gosta.
O Rock
O Sertanejo
O Pop
O MPB
O Heavy Metal
O Samba
O Hip-Hop
O Axé
O Eletrônica
O Funk 
Q4 Em quantos dias de festival você esteve presente na edição do rock in Rio $2013 ?$

○ 1

○ 2

○ 3

○ 4

○ 5

○ 6

○ 7

Q5 Enumere de 1 a 5 quais atributos mais te desanimaram em frequentar o festival Rock in Rio. Sendo 1 o que menos te incomodou e 5 o que mais te incomodou.

O Falta de estacionamento

O Multidão

O Alimentação

O Trajeto para chegar ao local

Alto valor dos ingressos

Q6 Por quais motivos você frequentou a edição do Rock in Rio 2013? Marque mais de uma opção se julgar necessário.

O Bandas/cantores que se apresentaram

Pelas atrações oferecidas ao público

O Queria conhecer o festival

Por influencia dos amigos e familiares

O Outros

Q7 Se você pudesse definir a marca Rock in Rio, em apenas uma palavra, qual seria? 
Q8 Considerando a lista abaixo, quais características você associa a marca do Rock in Rio? Fique à vontade para marcar mais de uma característica.

Alegria

Organização

O Desorganização

○ Multidão

O Harmonia

O Desconforto

O Emoção

Q9 Qual a primeira marca que vem à sua cabeça quando se lembra do festival Rock in Rio 2013?

Q10 Você concorda que o festival Rock in Rio, é um evento ideal para exposição das marcas?

O $\operatorname{Sim}$

O Não

Q11 Você considera que se tornou mais fiel à alguma marca, depois do Rock in Rio?

O $\operatorname{Sim}$

○ Não

Q12 Das marcas listadas abaixo, quais patrocinaram o Rock in Rio 2013? Das marcas listadas abaixo, quais patrocinaram o Rock in Rio 2013.

O Bob's

Oc Donalds

O Domino's

O Claro

O Oi

O Heineken

o Brahma

O Itaú
O Juventude

O Liberdade

O Magia / Sonho

O Rebeldia

O Popular
O Credibilidade 
O Correios

- GOL

O Trident

O Volkswagen

O Fiat

O Coca-Cola

O Guaraná

O Halls

O Mariner

O SKY

O Submarino

O TAM

O Wizard

O Chilli Beans

O Pepsi

O Estácio de Sá

Q13 Abaixo estão alguns entretenimentos oferecidos por algumas marcas patrocinadoras do evento na edição de 2013. Preencha as marcas que sediaram tais entretenimentos.

Roda Gigante

Tirolesa

Turbo Drop

Montanha Russa

Q14 Você vai ou pretende ir na próxima edição do Rock in Rio, aqui no Brasil? Marque apenas uma das condições abaixo.

O Não vou

O Iria com certeza

O Depende, principalmente do preço

Depende, principalmente das bandas 